University of Victoria: EWP0201 (ISSN 1485-6441)

\title{
A Comparison of U.S. and Canadian Residential Mortgage Markets
}

Marsha J. Courchane*

Director, Financial Strategy \& Policy

Research, Freddie Mac

8200 Jones Branch Drive

MS 484, McLean, VA 22102 USA

email: marsha_courchane@freddiemac.com

\author{
Judith A. Giles \\ Department of Economics \\ University of Victoria \\ PO Box 1700 \\ Victoria, BC, CANADA V8X 5A3 \\ email: jgiles@uvic.ca
}

March 2002

\begin{abstract}
As financial markets move toward increased globalization, it becomes worth considering whether inherent differences in financial markets across different countries will diminish. For two countries more similar than different in terms of geography, location, government and culture, Canada and the U.S. remain strikingly different in terms of housing finance. Public policy objectives toward housing followed quite different paths over the past seventy years and fundamental differences in banking practices have led to considerably different outcomes in terms of mortgage finance instruments in the two countries. In light of that, it is particularly surprising that homeownership rates do not diverge by much, reaching $67 \%$ in the United States and $64 \%$ in Canada by year-end 2000 .

We examine some of the differences in policy and in competitive practices between Canada and the U.S. in an attempt to illuminate why differences in rates and terms across the two countries still exist. While a part of the difference remains due to legal constraints concerning the finance of the domestic housing sector, we do not attempt an analysis of the legal structure and focus, rather, on the economics and public policy choices that have led to the observed differences.
\end{abstract}

\section{JEL Classification: R11, R21, R51}

Keywords: housing, mortgage finance, housing policy

\footnotetext{
* Corresponding author
} 


\section{Introduction}

While home ownership rates in Canada and the U.S. are remarkably similar, many of the characteristics of the housing finance markets in the two countries are decidedly different. In this paper, we will illustrate some of the most pronounced differences and offer some hypotheses as to why differences exist and whether we would expect to see the emergence of more homogeneity within North America as a consequence of the globalization of capital markets.

The United States does not, contrary to some assertions, exhibit an unusually large mortgage sector, relative to its GDP, when compared to Canada. Measuring the relative size of the domestic mortgage market in terms of the value of outstanding residential mortgage debt to GDP, the relative size of the residential mortgage market in the U.S. (53\%) exceeds that in Canada (43\%) even though several other developed countries have higher shares. ${ }^{1}$ Table 1 provides information on new housing investment relative to GDP and the stock of housing relative to GDP as of 2000 .

Table 1

Mortgage Sector Shares

\begin{tabular}{|l|l|l|}
\hline Country & NEW/GDP & STOCK/GDP \\
\hline & & \\
Canada & $2.12 \%$ & $43.0 \%$ \\
US & $4.57 \%$ & $53.0 \%$ \\
\hline
\end{tabular}

No country matches the United States in commonly offering both a thirty-year term to maturity and a mortgage rate fixed over the life of the loan and Canada has only recently introduced any instrument comparable. The average period of time over which the mortgage rate is fixed in Canada is considerably shorter than that in the U.S., whether the mortgage is adjustable-rate (ARM) or fixed-rate (FRM). Over all types of mortgages, the average mortgage term length in Canada is only 3 to 5 years, substantially shorter than that most commonly found in the United States (30 years). Loan-to-value (LTV) ratio requirements are similar in both countries, though Canada was much later than the U.S. in allowing for ratios higher than $75 \%$. Both countries require mortgage insurance for high LTV mortgages, though borrowers can often avoid this by taking a first mortgage at 75 or 80 percent LTV and a second mortgage (home equity line or line of credit) for the remainder.

Rates (and spreads) remain relatively lower in the U.S. than in Canada. As of 11/01/01, thirty year fixed rates in the U.S. averaged only 6.56 percent (the spread over 10 year Treasuries was at about 1.33 percent). The longest fixed term that could be found in Canada (at Royal Bank) was 25 years, and it came with a large price differential relative to the U.S. However, ignoring fixity of term, rates were generally higher on Canadian mortgages, while 10 year Treasury bond rates remained similar across the two countries, leading to relatively higher priced mortgages, in investment terms, in Canada than in the U.S. Table 2 provides the data from $7 / 19 / 01$.

\footnotetext{
${ }^{1}$ See Courchane and Nickerson (2001).
} 
Table 2

Current Rates and Terms: October 31, 2001 ${ }^{2}$

\begin{tabular}{|l|l|l|l|l|}
\hline Country & Mortgage Rate & Term & 10 yr Treasury Bond rate & Spread \\
\hline Canada & $6.15 \%$ & 3 year fixed & $4.86 \%$ & $1.29 \%$ \\
\hline Canada & $8.25 \%$ & 10 year fixed rate & $4.86 \%$ & $3.39 \%$ \\
\hline US & $6.56 \%$ & 30 year fixed & $4.44 \%$ & $2.12 \%$ \\
\hline
\end{tabular}

\begin{tabular}{|l|c|c|c|c|c|c|c|c|}
\hline \multicolumn{7}{|c|}{ The Current CIBC Mortgage Prime Rate is 4.50\% } \\
\hline \multicolumn{1}{|c|}{ CLOSED MORTGAGES } & $6 \mathrm{mos}$ & $1 \mathrm{yr}$ & $2 \mathrm{yr}$ & $3 \mathrm{yr}$ & $4 \mathrm{yr}$ & $5 \mathrm{yr}$ & $7 \mathrm{yr}$ & $10 \mathrm{yr}$ \\
\hline Fixed Rate & & $4.95 \%$ & $5.70 \%$ & $6.15 \%$ & $6.60 \%$ & $6.90 \%$ & $7.65 \%$ & $8.25 \%$ \\
\hline Convertible & $5.30 \%$ & & & & & & & \\
\hline Better Than Prime Variable Rate & & & & & & $3.49 \%$ & & \\
\hline Variable capped rate & & & & & & $5.60 \%$ & & \\
\hline Capped rate during term & & & & & & $7.70 \%$ & & \\
\hline \multicolumn{1}{|c|}{ OPEN MORTGAGES } & $6 \mathrm{mos}$ & $1 \mathrm{yr}$ & $2 \mathrm{yr}$ & $3 \mathrm{yr}$ & $4 \mathrm{yr}$ & $5 \mathrm{yr}$ & $7 \mathrm{yr}$ & $10 \mathrm{yr}$ \\
\hline Variable Rate Open & & & & & & $4.50 \%$ & & \\
\hline Fixed Rate Open & $5.75 \%$ & $5.75 \%$ & & & & & & \\
\hline
\end{tabular}

*This rate is the current special rate of $1.01 \%$ below CIBC (Canadian Imperial Bank of Commerce) Mortgage prime, which is valid for the first nine months. After that the rate reverts to $0.25 \%$ below prime.

Even with the difference in rates and terms, Canada has a rate of homeownership quite comparable to that of the United States. In a survey of twenty developed countries, most countries have rates from approximately ten to thirty percentage points lower than that of the U.S. However, in 2000, the rate of homeownership in Canada was 64 percent, while that in the U.S. was 67 percent. Owner occupancy rates were similar: 64.7 percent in Canada and 67.1 percent in the U.S. ${ }^{3}$

What explains this difference? Clearly Canadians pay relatively higher mortgage rates, often seem to require relatively higher down payments, and bear much more interest rate risk than American homebuyers. In addition, Canadian homeowners lack the income tax incentives provided to Americans through home mortgage interest deductibility. Still, as evidenced by the high rate in Canada, homeownership is clearly valued. In this paper we will explore some of the historical trends in public policy relating to housing, and some of the characteristics of the

\footnotetext{
${ }^{2}$ http://www.bank-banque-canada.ca/en/bond-look.htm http://www.cibc.com/pl_mortgage_rates.html http://www.federalreserve.gov/releases/H15/update/ http:/www.bank-banque-canada.ca/en/bonds.htm

${ }^{3}$ Owner occupancy rates may differ from homeownership rates, in calculations for countries other than the U.S.'s, when, for example, the number of households differs from the number of housing units (such as when a household owns multiple homes), and when data for rental markets diverges from owner occupancy data.
} 
economies in the two countries, in an attempt to account for the similarity of homeownership rates, in the face of decidedly different costs.

\section{The Evolution of Public Mortgage \& Homeownership Assistance Programs}

In this section we detail and contrast the housing policies in the U.S. and Canada that resulted from specific public policy objectives in the two countries. While many of the programs still extant in the U.S. resulted from Great Depression policies, Canadian homeownership programs tend to have been more recent.

\section{United States}

Many of the programs that we observe today in housing finance markets in the U.S. have evolved from public policy programs established during the Great Depression. During this time, much focus was placed on ensuring that every American had the possibility of home ownership. The National Housing Act of 1934 (and its 1938 amendments) states that "the Congress affirms the national goal that every American family be able to afford a decent home in a suitable environment". An enabling factor was the incentive provided in the tax code in 1913. The code stipulated that mortgage interest would be a deduction against income taxes for all tax-paying Americans that chose to itemize deductions. This deduction remains one of the largest for the majority of homeowners today.

The Depression programs followed the tradition of the Federal Farm Loan Act of 1916. That act focused exclusively on providing credit for farm mortgages, but it established the practice of using credit support to affect public policy agendas in mortgage markets. This is clearly not the only means available to support policy. Housing policy in the United States has been comprehensive in its objectives for decades. We find its statement 42 U.S.C. $\$ 12702$ and have extracted a small part of that statement here:

The objective of national housing policy shall be to reaffirm the long-established national commitment to decent, safe, and sanitary housing for every American by strengthening a nationwide partnership of public and private institutions able ....(6) to provide every American community with a reliable, readily available supply of mortgage finance at the lowest possible interest rates.....

Clearly housing matters. This statement of policy includes aspects of mortgage finance (including rate determination), of federal assistance, of social policy and of income redistribution. Where did this comprehensive emphasis on housing policy come from? When the National Housing Act was passed in 1934, mortgage markets were troubled in many respects. Over two million construction workers became unemployed. Mortgage loan terms were difficult, often requiring fifty percent LTVs with terms of only $3-5$ years, followed by balloon payments. Only 4 in 10 households owned homes.

After the Federal Farm Loan Act of 1916, further assistance for farm lending came from the establishment of the Federal Home Loan Bank System (FHLBank System) through the Federal Home Loan Banks Act (FHLBAct) in 1932. The FHLBank System was established by Congress to increase liquidity in mortgage markets by providing a source of short-term funds ("advances") to approved primary mortgage lending institutions (savings and loan associations). Originally, only thrift institutions (savings and loan associations and savings banks) and 
insurance companies were allowed to be members of the FHLBanks. The FHLBAct also established the Federal Home Loan Bank Board, a regulatory agency intending to supervise the mission and safety and soundness of the Federal Home Loan Banks (FHLBanks). The FHLBanks have acted traditionally as sources of short-term credit for member institutions, which primarily held portfolios of long-term residential mortgage loans. Hence, the mechanism used for effecting housing policy in this instance was through the provision of low cost funding to the actual originators (the FHLBank members) of the mortgages. ${ }^{4}$

In 1933, another housing act, the Home Owners' Loan Act, provided for chartering and regulation of the savings and loan institutions (S\&Ls). These institutions were the primary lenders to homeowners during this period. Several other primary housing agencies were established during the Great Depression including, under the National Housing Act of 1934, the Federal Housing Administration (FHA). Its mission was to improve both housing standards and conditions and to provide "adequate" home financing through the insurance of mortgages. It was also intended to stabilize the mortgage markets. When the Department of Housing and Urban Development (HUD) was established in 1965, FHA was consolidated into HUD. While its mission today has broadened, its focus is housing. In particular, its mission currently includes contributing to building and preservation of healthy neighborhoods and communities, maintaining and expanding homeownership and rental housing, and stabilizing credit markets during economic disruptions. ${ }^{5}$ FHA pioneered the long term amortizing loan, instrumental in the prevalence of the thirty-year fixed rate mortgage in the United States. FHA continues to insure mortgages, insuring over 24 million since 1934, including 38,000 multifamily apartment projects.

While broader in scope than just housing support, the Federal Deposit Insurance Corporation (FDIC) was another Depression program created in 1933. The intent was to support the financial institutions that fund housing. Its express mission was, and remains today, to maintain the stability of and public confidence in the nation's financial system, through its insurance of deposits and its supervision of safety and soundness at state non-Federal Reservemember banks. Since its establishment, the U.S. has not witnessed bank panics such as those observed during the Great Depression, and it is in some large measure due to this that the funds are available to lend to homeowners.

While the programs above pertained to the primary market for mortgages, the Great Depression also led to the creation of a secondary market. Congress created Fannie Mae in 1938 to support housing through the purchase of FHA-insured loans. In fact, at its inception, Fannie Mae was part of the FHA. It channeled funds through mortgage originators of FHA loans, targeting investment funds to housing. While today Fannie Mae is private (as of 1968) and does not receive government funding, its mission focuses on increasing the affordability and availability of homeownership for low-, moderate-, and middle-income Americans. Fannie Mae

\footnotetext{
${ }^{4}$ The FHLBanks remain important participants in U.S. housing finance. Advances have grown substantially over time. As of December 31, 2000, there were approximately $\$ 438$ billion in advances outstanding. This represents an increase of $231 \%$ in the level of advances outstanding since December 31, 1995. Thrifts still account for the majority of advances, borrowing $58.2 \%$ of total advances at the end of 2000 . But thrifts' share of advances has fallen from $72.5 \%$ at the end of 1995 . Commercial banks have correspondingly increased their share of total advances from $24.6 \%$ in 1995 to $39.3 \%$ in 2000 .

${ }^{5}$ http://www.hud.gov/fha/fhaabout.html accessed on 3/25/02.
} 
and the FHLBank System are two of the government-sponsored enterprises (GSEs) that comprise the secondary mortgage market in the U.S. The third, Freddie Mac, was established in 1970 as the Federal Home Loan Mortgage Corporation (FHLMC) and is subject to the same mission and safety and soundness regulation as is Fannie Mae. Their mission regulator is HUD, while their safety and soundness regulator, as of 1992, is the Office of Federal Housing Enterprise Oversight (OFHEO). All three of the GSEs support housing through the mortgage finance mechanism of providing funding to other institutions that actually originate the home loans. However, only the FHLBanks can also originate mortgages. ${ }^{6}$

Additional federal programs provided some support for the housing and mortgage markets in the U.S. For example, the Veteran's Administration (VA) was established in 1944 under the Serviceman's Readjustment Act, to enable servicemen returning from the war to obtain low cost housing funds. The Farmer's Housing Act (FmHA), later the Rural Housing Service (RHS), provided farm and rural housing loans. The establishment of HUD in 1965 moved many of these programs under a central administrative authority. Ginnie Mae, established through the Government National Mortgage Association (GNMA) (1968) served low- and moderate-income borrowers and guaranteed FHA, VA and RHS loans, essentially assuming the credit risk and providing an incentive to lenders to fund these loans relative to conventional (non-governmentinsured) loans.

The timeline illustrating the establishment of the federal housing programs in the U.S. follows in Table 3.

Table 3

\section{United States Federal Homeownership Programs}

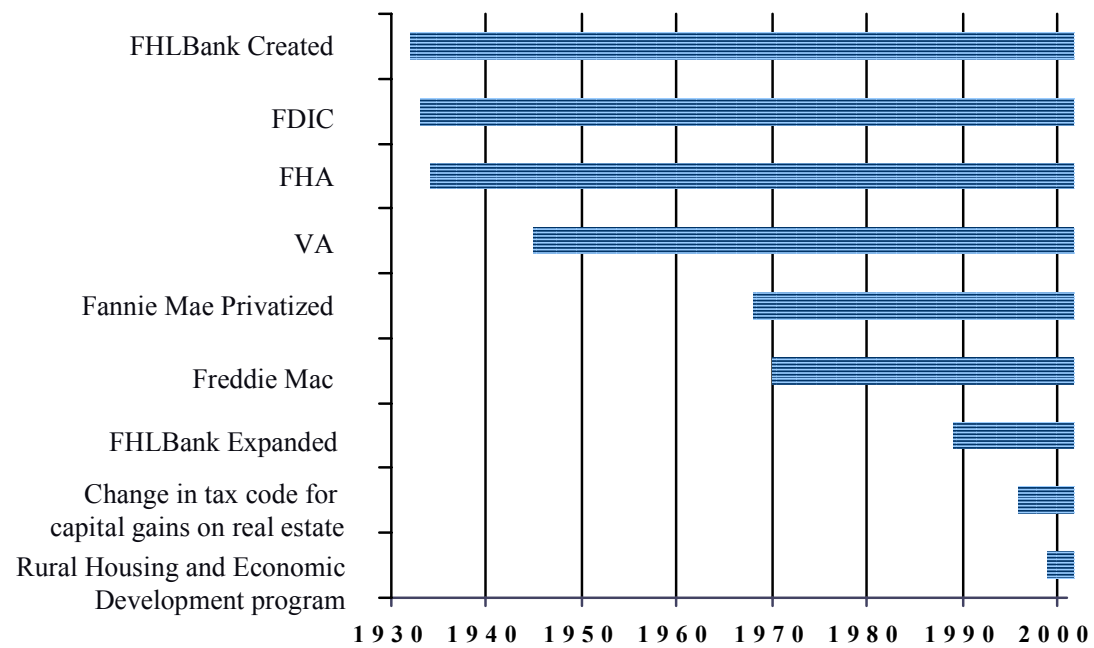

While the above discussion only briefly mentions a few of the many public policy programs and objectives that support and finance housing in the U.S., even this brief discussion highlights

\footnotetext{
${ }^{6}$ The origination of mortgages through direct mortgage acquisition programs such as the Mortgage Partnership Finance (MPF) program is a recent phenomenon at the FHLBanks.
} 
the importance that public policy has placed on homeownership. Much of the U.S. public policy focus has been on public and private partnerships that focus on the supply side of funding - not direct subsidies to homeowners.

\section{Canada}

The Canadian federal government supports homeownership through the Canadian Mortgage and Housing Corporation (CMHC), a federal crown corporation (similar in some respects to a U.S. government-sponsored enterprise) that was created in 1954 to be the Canadian government's national housing agency, established to provide access for Canadians to a wide choice of quality, affordable homes. The broad mandate of the CMHC is to promote the construction of new houses, the repair and modernization of existing homes, and the general improvement of the living conditions for Canadians. The focus has been, and continues to be, on the supply of housing units in the private sector, with the approach being on introducing a series of programs designed to make homeownership a practical option and to assist in reducing the likelihood of mortgage defaults. This is significantly different from the federal government support in the U.S. that focuses more on market financing and market stability and much less on direct schemes to assist homeowners to acquire, and remain in, homes. ${ }^{7}$

We outline the Canadian programs that have been instigated since 1935 in Table 4.

Table 4

\section{GandanFederal HoneowershipHograns}

1930 to 2000

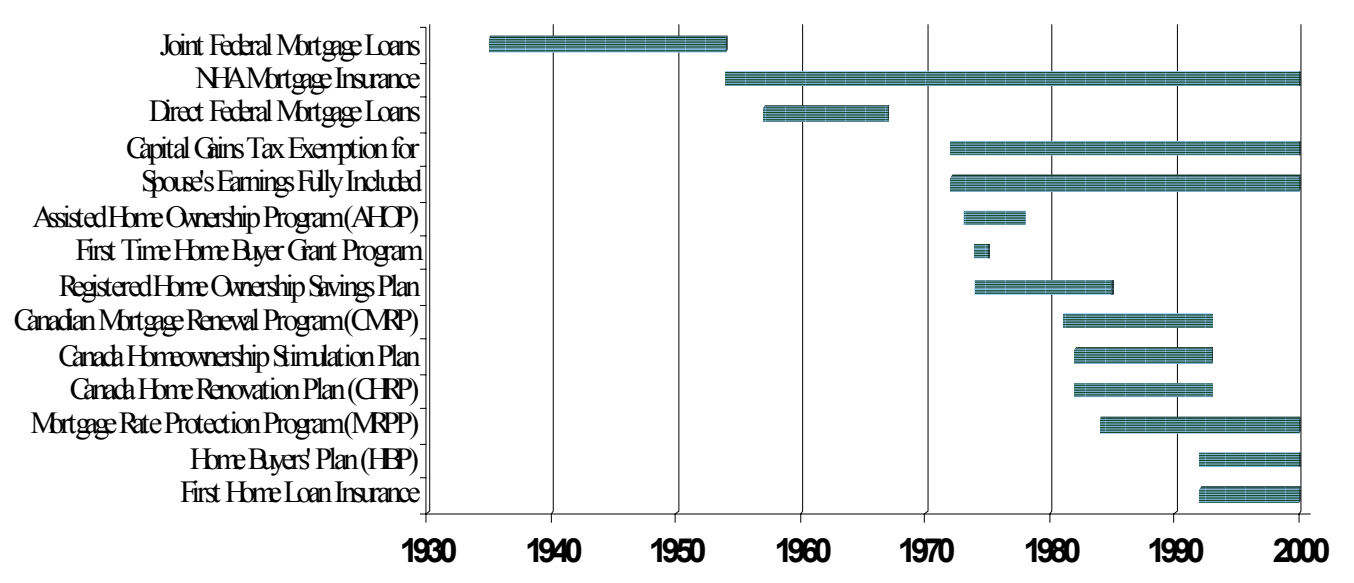

As can be seen by comparing Tables 3 and 4, the timing and evolution of public policies toward housing were quite different in the U.S. and Canada. There were two key reasons why no national housing policy existed in Canada until recently. First, Canadians shared roughly similar housing circumstances so that few thought they were disadvantaged. In fact, the prevalent social

\footnotetext{
${ }^{7}$ There have also been some market support initiatives and various social housing and rehabilitation programs, which we will not examine here given our focus on the mortgage markets; see, e.g., Van Dyk (1995) and Carter (1997).
} 
perspective was that financial difficulties implied moral degeneracy (Anderson, 1992). Secondly, governments had limited funds with which they could intervene, even if desired. The Canadian Federal government only chose to become involved in housing matters after the Halifax ship explosion in December 1917 that killed over 1600 people and virtually flattened the city. At the end of the First World War, the Canadian federal government provided approximately \$25 million in loans for housing. The first national housing program, which lasted from 1919 to 1923, provided over 6,200 dwelling units in 179 municipalities, but was regarded as wasteful and inefficient (Anderson, 1992). During this period, the government's general tenet indicated a preference for reliance on the private market to provide housing.

Just as in the U.S., the Great Depression brought serious housing shortage problems. Subsequent to several government reports, the Dominion Housing Act (DHA) of 1935 authorized the Minister of Finance to join with lending institutions or local housing authorities to loan funds for new housing construction, but not for renovation of existing housing stock. The Bill introduced the concept of blended payment mortgages, risk absorption by the government and longer amortization periods. Notably, the DHA did not establish a national housing agency despite numerous discussions in Parliament, and it capped the mortgage interest rate at five percent, despite numerous complaints from lending institutions (Hulchanski, 1990). In 1937 the Canadian government introduced the Home Improvement Loans Guarantee Act that allocated funds for renovations. This program persisted until the late 1980s but with very limited success.

Just a few years after the U.S. NHA was passed, in 1938 Canada passed its first National Housing Act (NHA) reaffirming the DHA while making available far more funds for loans. In forty-four months there were 15,000 loan applications (Anderson, 1992). Further legislation just before the Second World War provided for the Central Mortgage Bank, operated by the Bank of Canada, which permitted any financial institutions to join by agreeing to keep mortgages for farms at rates not to exceed 5 percent and on homes not to exceed 5.5 percent. Though only short-lived, the Central Mortgage Bank was the precursor to the $\mathrm{CMHC}^{8}$, and reaffirmed that, in Canada, the government intended to confine itself to activities in the housing market that avoided conflict with the private sector.

No further housing legislation was introduced until 1944, apart from the creation of Wartime Housing Limited in 1941 (similar to the U.S. VA), whose mandate was to assist house munitions workers and their families. In 1944, the Curtis Report ${ }^{9}$, one of several reports requested by the government on housing issues, recommended, among other things, that equity for mortgages be reduced to 10 percent from 20 percent and that the government provide mortgage insurance to assist middle- and low-income families to qualify for loans. The subsequent 1944 NHA fell far short of the recommendations as it only provided initiatives for new housing construction in the post-war period. The government moved closer to a national housing policy with the 1945 Central Mortgage and Housing Act that allowed for a crown corporation that would serve as an instrument for public housing policy and an administrator of federal housing funds. The first task of the CMHC, similar to the U.S. VA, was to house the families of veterans. However, the chronic shortage of affordable housing remained and there were still insufficient mortgage funds available.

\footnotetext{
${ }^{8}$ Indeed, David Mansur, the first General Superintendent of the Central Mortgage Bank became the first President of the $\mathrm{CMHC}$.

${ }^{9}$ Named after one of its authors, W.A. Curtis of Queen's University.
} 
The housing situation deteriorated even further following the post-War baby boom coincident with high immigration. Immigration in 1952 increased more than ten fold and totaled 221,000 relative to only 15,000 in 1945 . The 1954 NHA attempted to address the housing finance shortage by enabling chartered banks, for the first time, to provide government mortgage loans, with CMHC providing mortgage loan insurance. This insurance program, financed by borrower premiums, is still intact. This compares, broadly, to the provision of mortgage insurance by Ginnie Mae on FHA, VA, and RHS loans in the U.S. The new Act was successful - in one year the number of new loans jumped by more than a third, and between 1954 and 1956, banks provided mortgages for more than half of the homes built under NHA. The insurance is available for both new homes and existing units, though initially it was only for new homes. Currently, a loan-to-value ratio of 75 percent is the cutoff for the requirement for default insurance (compared to the 80 percent cutoff in the U.S). The introduction of this program increased mortgage funding under NHA, particularly from banks, which had been reluctant to enter the government mortgage market. The total value of outstanding mortgages insured by CMHC exceeded $\$ 200$ billion in 2000 (CMHC, 2001), and over 460,000 mortgages were insured in that year.

While chartering banks for residential lending under NHA was initially successful, by 1957, which marked an economic downturn as well as the end of a long era of a Liberal Canadian government, the banks were failing to provide adequate mortgage funds as a result of the (then) 6 percent legislated ceiling on mortgage interest rates. In the decade from 1957 to 1967, the CMHC funded more homes than did the banks. This led the government to introduce a new formula for setting the NHA mortgage interest rate in 1966, and finally led to deregulation of interest control in June 1969, so that the only difference between NHA and conventional loans was the default protection provided by the mortgage insurance for the NHA loans (Hulchanski, 1990). These initiatives followed a slump in housing starts. Simultaneously, the term for NHA loans was reduced from 25 years to five years, and then to three years in 1978. This reduced the interest rate risk of lenders and so provided an incentive for private sector funding of mortgages; but it simultaneously shifted the interest-rate risk to borrowers, while providing them a range of term options to help limit the risks. Clearly both of these changes were made to persuade lenders to become more vigorous participants in housing finance. It is unclear why both changes were made simultaneously but clearly both benefited the banks and imposed costs on homeowners.

Various programs were implemented during the 1970s and 1980s, periods of high and unstable interest rates, to assist homeowners meet their payment schedules and to protect them from the rapidly rising rates, which were seriously impacting payments, given the short-term loans commonly offered by institutions. Home buying in urban areas became especially difficult, even for two income families, with the unprecedented house-price inflation. For example, between 1972 and 1974, the average Multiple Listing Service ${ }^{10}$ (MLS) sale price increased from $\$ 26,595$ in 1972 to $\$ 41,057$ in 1974, a change of 54 percent (Fortin and Leclerc, 1999) while the average Canadian salary increased by only 22 percent (Hulchanski, 1990). Fortin and Leclerc estimate the change in the real housing price between these two years at 29 percent. Further evidence of the homeownership crisis is given by the decline in the CMHC's measure of the percentage of renters of prime home-buying age ( 25 to 44 years old) able to buy

\footnotetext{
${ }^{10}$ The Canadian Real Estate Association MLS price is based on a record of the real estate transactions conducted in the nation's different cities. Approximately $90 \%$ of the properties sold are residences.
} 
the average-priced house. This index fell from 50 percent in 1971 to 17 percent in 1975 and to 7 percent in 1981 (CMHC, 1985).

The Assisted Homeownership Program (AHOP), introduced in 1973 when over thirty-six amendments were made to the NHA, provided borrowers with monthly payments from CMHC intended to equate their net monthly mortgage payment to that which would result under an 8 percent per annum interest rate. These interest reduction loans were secured by a second mortgage, but were interest free for five years. The provincial governments also assisted by augmenting the grants received by first time homeowners enrolled in AHOP. The program was discontinued in 1978 as a result of high default ratios in regions where house capital appreciation was not sufficient to cover the high ratio first mortgage and second mortgage debts (Jones, 1998). Over 94,000 households enrolled in the program (Hulchanski, 1990). In 1974 another program was instigated that provided cash grants for downpayment assistance (First Time Home Buyer Grant Program). In 1972, lenders were required to consider any or all of a spouse's earnings, rather than the 50 percent limit imposed in 1968 (Carter, 1997).

The CMHC and provincial governments also tried other programs to alleviate the real payment tilt burden and assist the housing market during the early 1980s slump. The gross debt service ratio used in the loan underwriting process was gradually increased from 23 percent of gross income in 1945 to 32 percent in the early 1980s (Carter, 1997). The Canada Mortgage Renewal Program (CMRP), introduced in September 1981, provided assistance to those renewing loans in the form of grants and deferred interest options. This was curtailed in late 1983 with the CMHC replacing it in 1984 with the Mortgage Rate Protection Program (MRPP) that provided insurance protection from interest rate increases to those holding NHA mortgages. Perhaps not surprisingly, given its implied catastrophic risk, the program was prohibitively costly to the loan holder (a flat premium of 1.5 percent of the loan) and restrictive in benefits (e.g., a $\$ 70,000$ maximum loan size, 12 percentage point cap on interest rate increases). Predictably, given declining interest rates, few borrowers have availed themselves of the protection (Lea and Bernstein, 1995; Jones, 1998).

An alternative approach to promote homeownership from these mortgage-based plans (e.g., low-downpayment and government insurance), encourages household savings for downpayments. ${ }^{11}$ Unlike the U.S., the Canadian government has used several such schemes over the years. The Registered Home Ownership Savings Plan (RHOSP), begun in 1974 and ended in a tax reform measure by the Conservative government in 1985, enabled renters (each spouse in the case of a married couple) to establish a RHOSP account in which deposited funds (limited to $\$ 1,000$ per annum) were tax deductible and the interest earned was free of income tax. ${ }^{12}$ Participation peaked around 20 percent for renters aged 25 to 29 years and then declined with age, though over time a greater proportion of households with heads aged 35 to 39 participated. Contributors to RHOSP had higher median incomes than non-contributors, so the program likely benefited higher-income households more than lower-income households (Engelhardt, 1997). Moreover, Engelhardt (1996) shows that most contributions to this savings program constituted new net savings, which leads him to recommend the use of such a targeted tax-based savings

\footnotetext{
${ }^{11}$ Some suggest that subsidizing savings is perhaps preferable to attempting to lower default probabilities; e.g., Lea and Renaud (1994).

${ }^{12}$ Lifetime individual contributions were limited to $\$ 10,000$ plus earnings, previous homeowners were not eligible, and withdrawals could be made only once and had to be for the total accumulated in the account.
} 
program for the U.S., assuming that household behavior for the U.S. is similar to that for Canadians. However, a variety of very low downpayment programs are available for homeowners in the U.S. Targeted savings plans impose clear costs on the federal government (foregone tax revenues) and were necessitated by the lack of program offerings provided by the private lenders in Canada.

Similar assistance plans included the Canada Homeownership Stimulation Plan (CHOSP), introduced during the 1982 downturn, which provided \$3,000 cash grants to help with home purchases, and the Canada Home Renovation Plan (CHRP), also begun in 1982 to further stimulate residential construction, which made available up to $\$ 3,000$ in a cash grant. These programs, though popular, were expensive and typically failed to assist lower-income households. CMHC (1986) estimates that the CHOSP cost \$800 million, CHRP \$230 million and Dowler (1983) reports that the RHOSP costs about $\$ 100$ million per year.

The federal government introduced the Home Buyers' Plan (HBP) in 1992 to assist would-be homeowners raise sufficient downpayment funds. It allows Canadians to withdraw up to $\$ 20,000$ from their RRSPs (Registered Retirement Savings Plans ${ }^{13}$ ). ${ }^{14}$ It is difficult to ascertain whether the program has resulted in simply a transfer of funds from RRSP savings to homeownership or in a net gain in tax-sheltered savings. ${ }^{15}$ In 1992, the CMHC extended its insurance program through the introduction of the First Home Loan Insurance (FHLI) program, allowing first-time homebuyers to have $95 \%$ LTVs and still qualify for CMHC insurance. ${ }^{16}$

Apart from these described savings programs, the government has not used the tax system to stimulate homeownership, except to exempt the family home from capital gains tax in 1972, thereby enabling home owners to fully benefit from capital appreciation. The foregone revenue from tax exemption of capital gains on houses is estimated to be well in excess of $\$ 1.5$

\footnotetext{
${ }^{13}$ RRSPs are tax-sheltered savings plans created to provide retirement income with deposits that can be deducted from taxable income up to a limit, which is currently based on 18 percent of earned income, up to a maximum allowable of $\$ 13,500$.

${ }^{14}$ The funds are exempt from income tax as long as the RRSP is refunded in equal installments over a 15 -year period. Up to two partners in the home can combine their RRSPs for a total maximum of $\$ 40,000$. The program was originally only for a short time and all homebuyers could use it. The temporary nature of the plan restricted its initial use, even though it was extended twice. It was made permanent in March 1994 and limited to those who had not owned a home in the previous five years. The latter restriction curtailed some use of the program, as many households are unable to deposit funds into RRSP accounts until they have achieved homeownership. In its first two years over 250,000 individuals took advantage of the Plan while in 1999 the program assisted more than 105,000 individuals, who withdrew more than one billion dollars from their RRSPs with an average withdrawal of approximately $\$ 10,000$ (CMHC, 2000a).

${ }^{15}$ One appealing feature of the plan is that money can be borrowed from financial institutions to top up RRSP funds, which can then be used to meet the HBP requirements. This then allows the borrower to obtain a large tax rebate by claiming the eligible RRSP contribution against the current year's income; this would not be possible if funds were directly borrowed to meet downpayment requirements.

${ }^{16}$ CMHC further enhanced its mortgage insurance program in 2000 by adding a new pre-qualification plan that provides approval for mortgage loan insurance in advance of a home purchase, and a new refinancing package that no longer limits borrowers when acquiring a second mortgage loan or adding to an existing mortgage to using the funds for renovations and property improvements.
} 
billion annually. Unlike the U.S., Canada does not allow homeowners to deduct mortgage interest and property tax payments from taxable income, despite this being in the election platforms in 1978 and 1989.

While there is much debate in both political and academic circles on mortgage interest deductibility, (e.g., Green and Vandell (1999), Dreier (1997), Voith (1999), Bourassa and Grigsby (2000) and the associated comment articles by Weicher (2000) and Vandell (2000)), the Canadian government remains unconvinced even though some research suggests that the demand for mortgage debt is highly responsive to changes in the mortgage interest deductibility (e.g., Follain and Dunsky, 1997). ${ }^{17}$ Unlike Canada, the U.S. continues to allow home mortgage interest deductibility for several reasons. Congress believes that the tax concessions encourage homeownership; that eliminating the deductions may cause a significant drop in the market value of homes (e.g., Capozza et al., 1997); that distortions in the tax code may increase rather than decrease (e.g., Woodward and Weicher, 1989) if the deductions are eliminated; that the volume of housing construction is higher with the deductions than without ${ }^{18}$; and finally, Congress may be persuaded by the political lobbying of several housing trade associations (Bourassa and Grigsby, 2000).

In summary, while the Great Depression engendered National Housing Acts in both the U.S. and Canada, the subsequent approaches of public policy towards housing differed significantly in the two countries. The U.S. focused on stimulating the provision of funds to housing through the establishment of government-sponsored enterprises (FHLBanks, Fannie Mae, Freddie Mac) but without interference in pricing mechanisms (such as interest rate caps). Canada had more limited success in targeting funds to housing, partly because they capped prices that private institutions could charge for mortgages. The U.S. uses the tax code to stimulate homeownership. Canada does not. Rather, it attempts to stimulate private investment in housing through support of housing savings programs. Finally, the secondary market in Canada is much less well established than that in the U.S., certainly implying that the availability of funds for housing depends more on just a few large lenders (given the concentration of banking in Canada) than on funds raised through global capital markets. In spite of these considerable differences, both countries have achieved notable success in attaining high homeownership rates.

\section{Market Structure and Factors Affecting Mortgage Demand}

Many factors beyond explicit public policy influence homeownership rates. For example, changes in demographics are important and might well affect the rates in the two countries differently by differentially impacting housing demand or supply. In order to determine if the demographics are sufficiently different to influence mortgage market outcomes, we start by providing some descriptive statistics for mortgage markets in the two countries.

\footnotetext{
${ }^{17}$ Bourassa and Grigsby (2000) estimate that it is advantageous for approximately 45 percent of U.S. homeowners to itemize these two deductions on their tax returns. Others argue (e.g., Baer, 1975; Dreier, 1997; Pierce, 1989) that the allowances should be eliminated on equity and allocative efficiency grounds, as they favor the higher-income homeowner and homeowners over renters (e.g., Goode, 1960; White and White, 1977; Hendershott and Hu, 1981).

${ }^{18}$ Though Bourassa and Grigsby (2000) argue that as homeownership is an American dream, the deductions do little to encourage additional residential construction.
} 


\section{A. Mortgage Markets}

\section{United States}

Homeownership rates have increased steadily in the U.S. As of year-end 2000, $67.1 \%$ of Americans were homeowners. Rates have increased particularly sharply since 1994 as shown in Table 5 below as both pricing and affordability have been affected by the favorable economic climate in the U.S. in the past decade.

\section{Table 5}

\section{U.S. Homeownership Rates Since 1982}

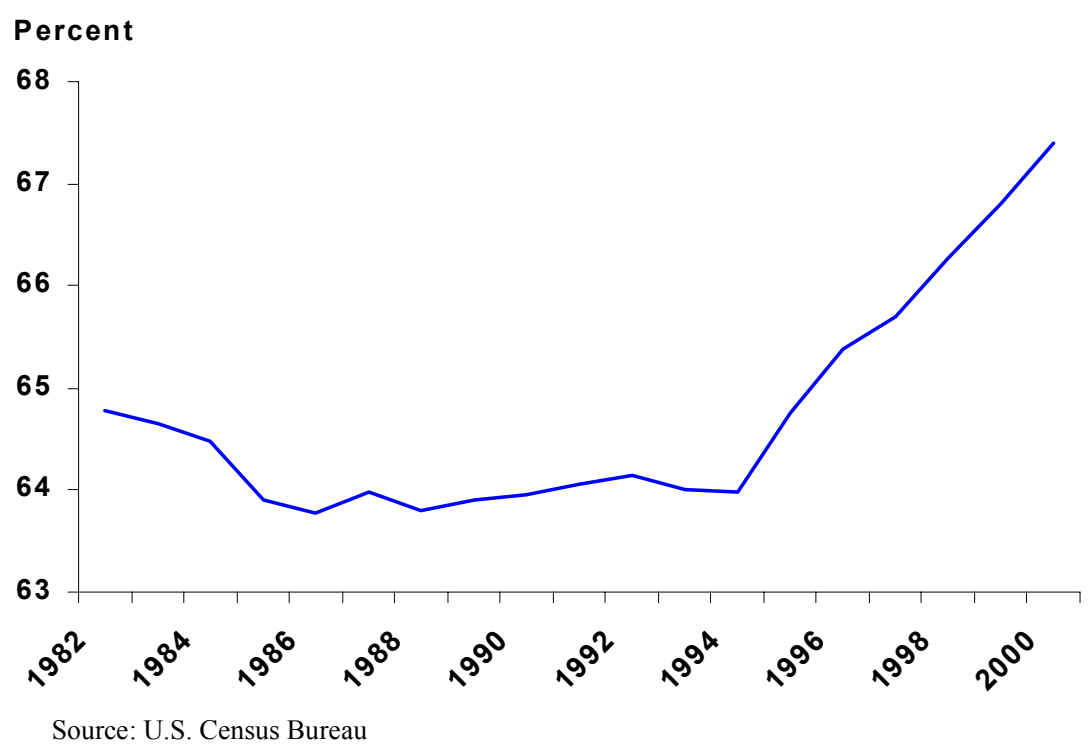

Americans continue to indicate a very strong preference for homeownership. As exhibited in Table 6 , mortgage originations are rising steadily. 
Table 6

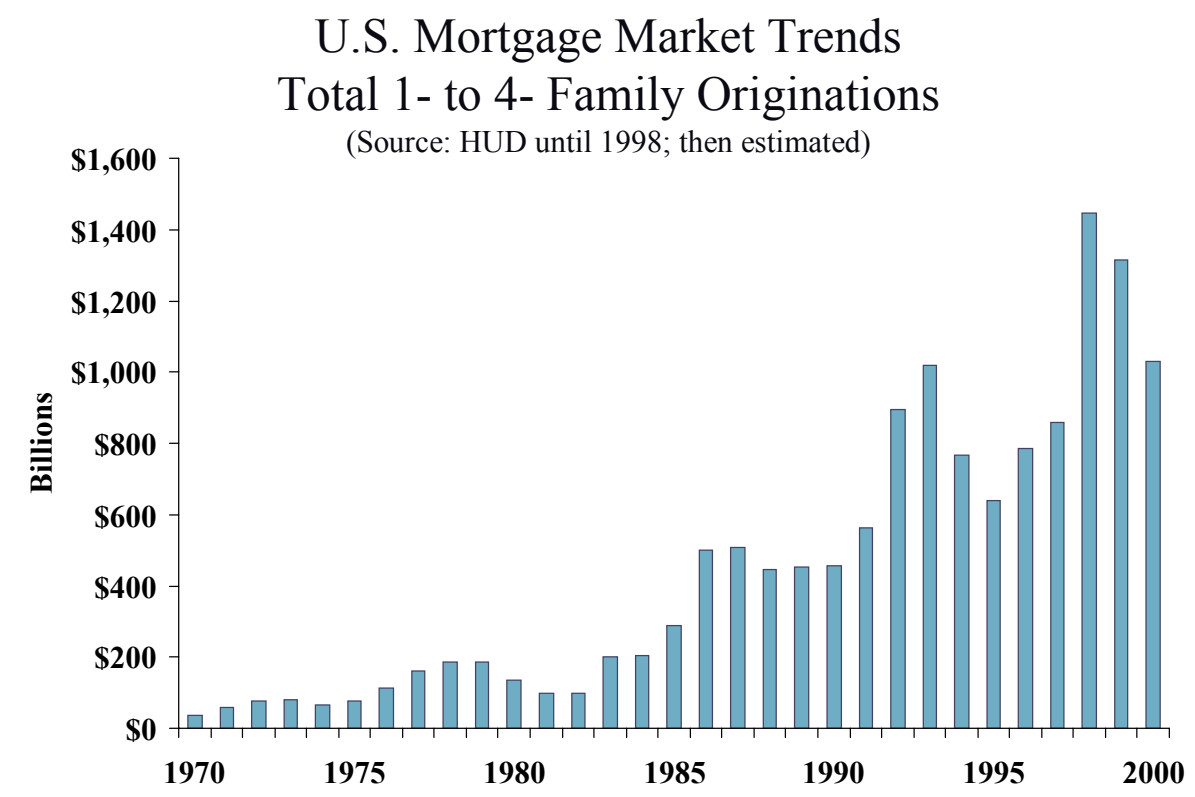

As a factor in the economy, housing remains important. The share of mortgage debt relative to GDP is provided in Table 7.

Table 7

U.S. Mortgage Debt Outstanding (MDO) and GDP

(Source: Federal Reserve Board and BEA)

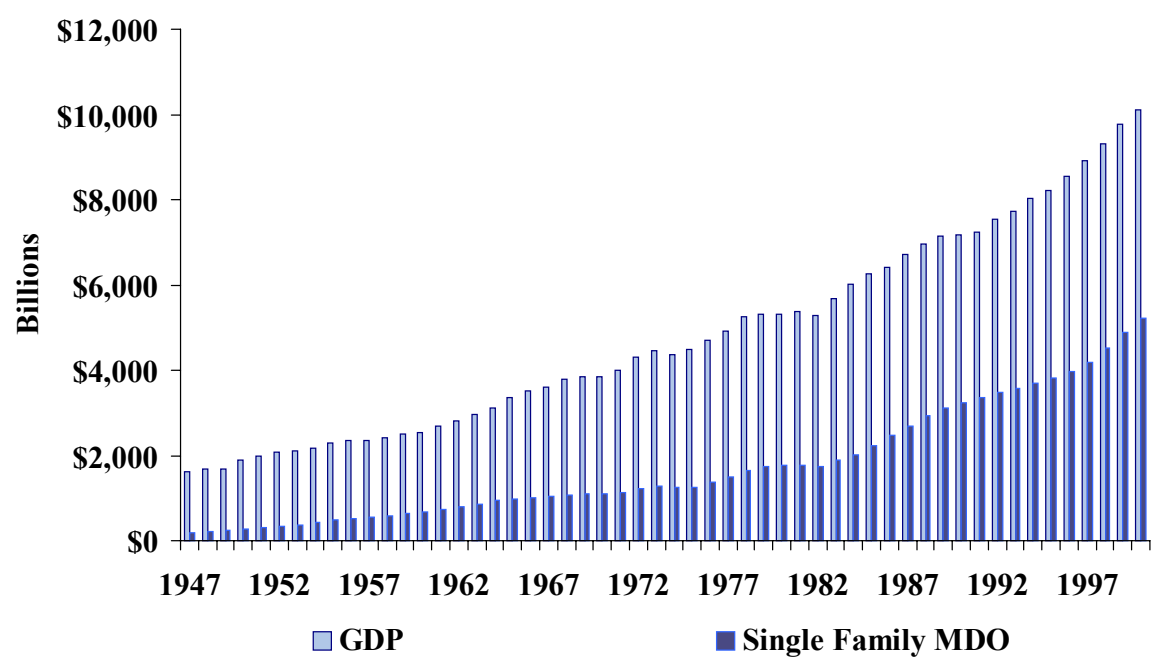

Different parties, depending, in part, on the type of mortgage originated, hold the mortgage debt outstanding. The principal types of residential mortgages loans in the U.S. are uninsured conventional loans, privately insured conventional loans (for those with high LTVs) 
and government insured (FHA and VA) loans. Approved private lending institutions originate government-insured loans using specific program. These loans can be pooled into mortgagebacked securities through Ginnie Mae. All three types of loans are made on new construction, existing property and on dwellings for owner occupancy and rental. For the distribution, see Table 8.

\section{Table 8}

\section{U.S. Single Family Mortgage Debt Outstanding by Market (Source: Federal Reserve Board)}

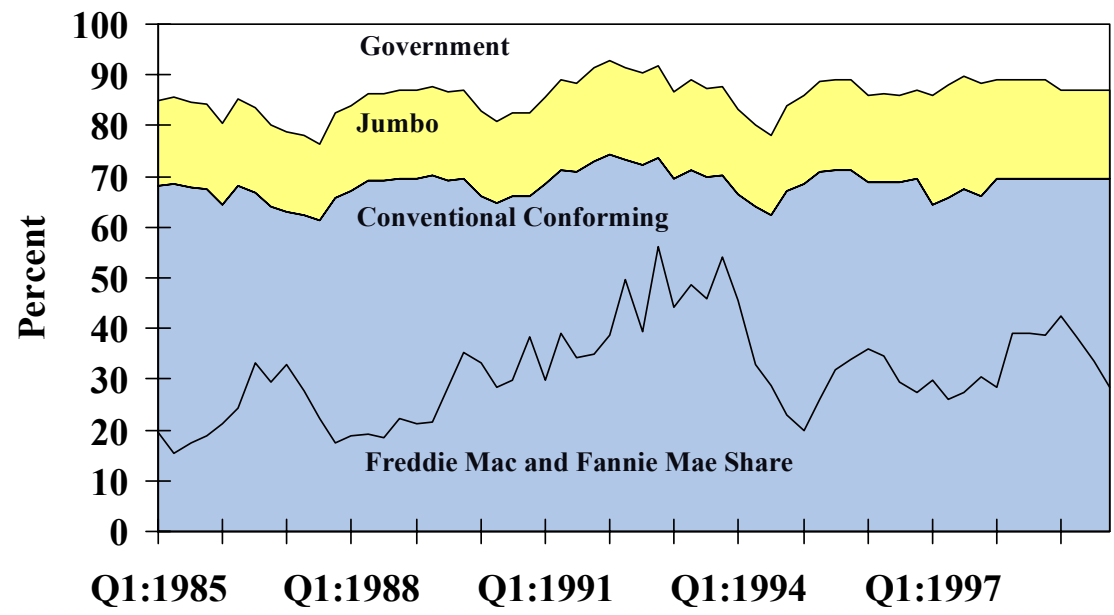

\section{Canada}

Canadians over the postwar period have also shown a strong preference for homeownership with approximately 64 percent of all households in 2000 being owneroccupants. Nearly half of homeowners carry a mortgage, which accounts, on average for approximately one-fifth of the household's disposable income. Table 9 illustrates the importance of housing expenditures in Canada's real GDP, while Table 10 provides the share of mortgage debt outstanding relative to GDP. Over 60 percent of this debt is held by chartered banks, that have, since 1969, increased their share by an average of 6 percent per annum. The trust and mortgage loan companies share has dramatically fallen, substantially due to the 1980 revision of the Bank Act, which allowed chartered banks to wholly own trust and mortgage loan companies. Securitization of mortgage loans in Canada began in 1987, unlike the long history in the U.S., and their share of the debt outstanding is still below 10 percent. For the distribution amongst the different parties, see Table 11 . 


\section{Table 9}

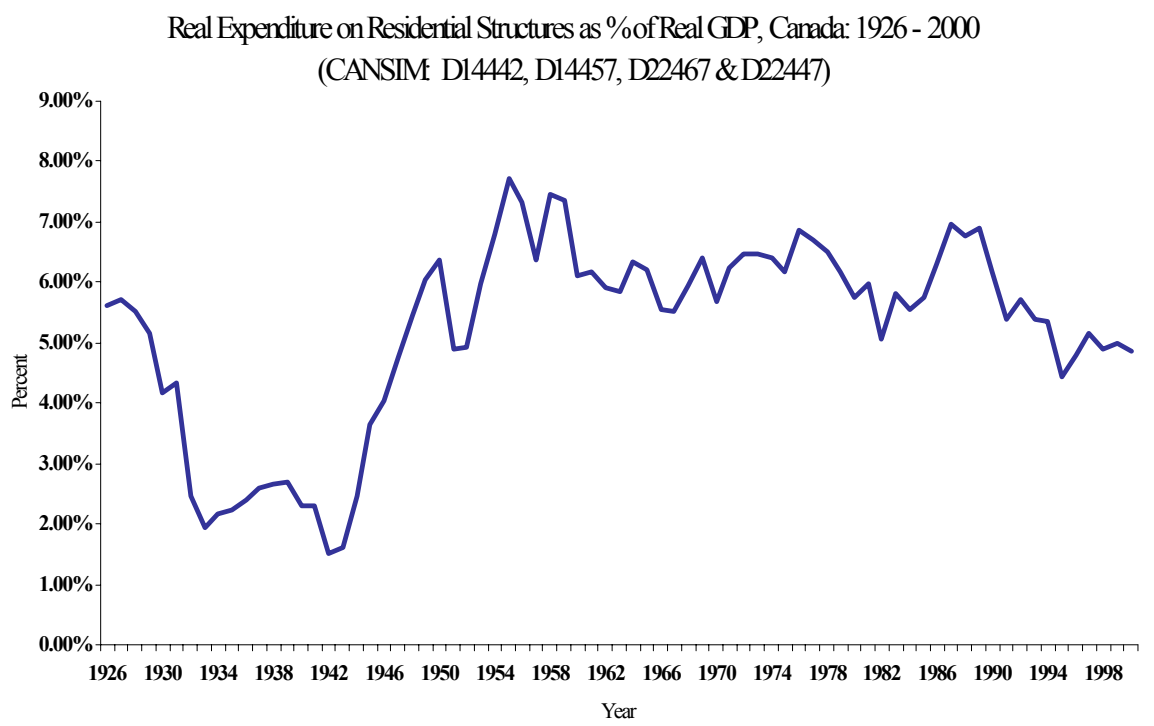

Table 10

Canada: Mortgage Debt Outstanding (MDO) and GDP

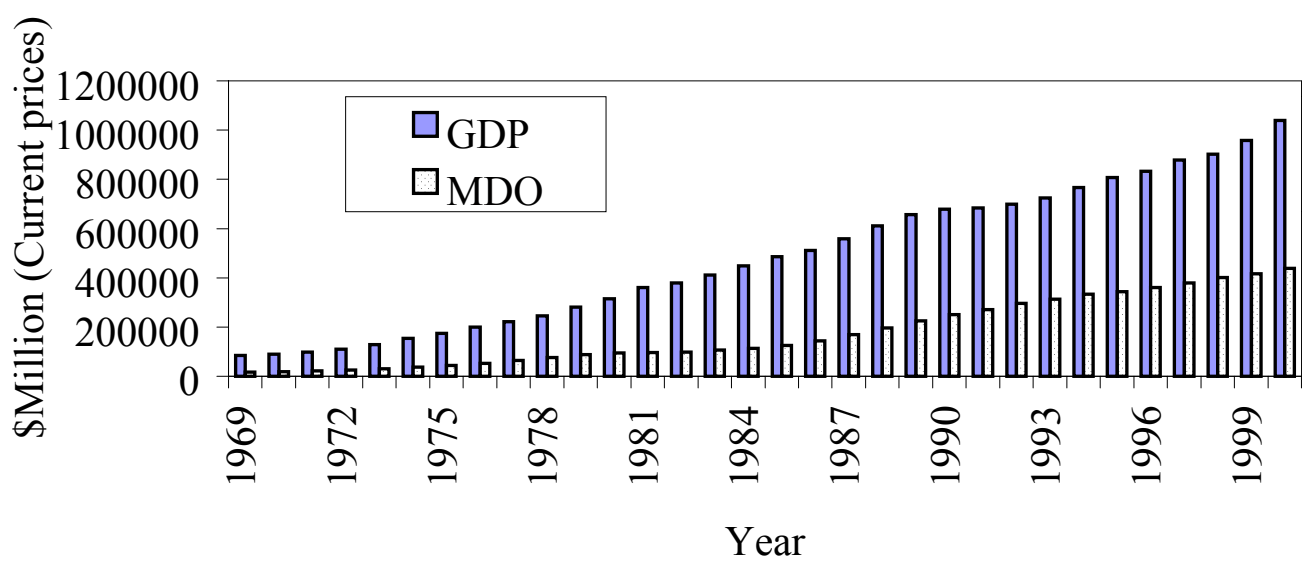


Table 11

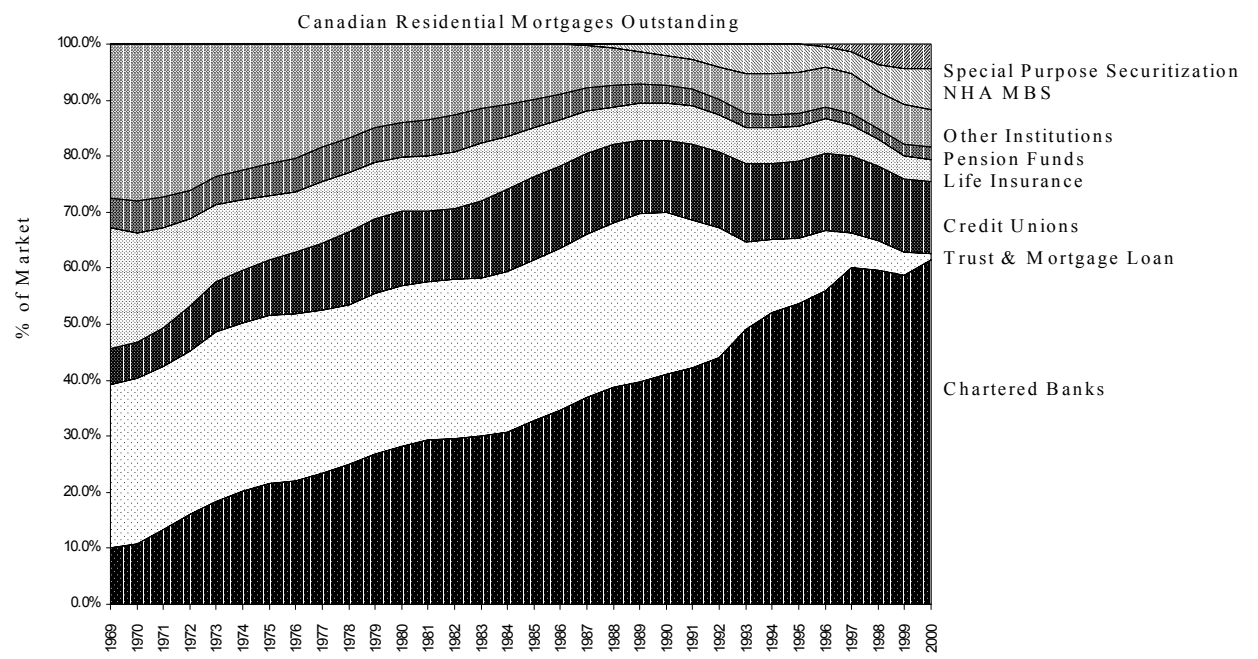

Mortgage lending grew rapidly in Canada over the 1950s and 1960s following the postwar boom in housing construction and immigration. Since the early 1980s, a period associated with volatile and high interest rates and the subsequent recession years, the annual number of government and conventional mortgage approvals on new properties grew steadily reaching a peak of 120 thousand approvals in 1990, then declined to a trough in 1995 with steady increases since then (see Table 12).

The volatility in mortgage approval growth is virtually identical to that for housing starts (see Table 13), as new homes are largely financed through loans. 
Table 12

Govt (NHA) and Conventional Mortgage Loan Approvals on New

Properties, 1956 to 1998

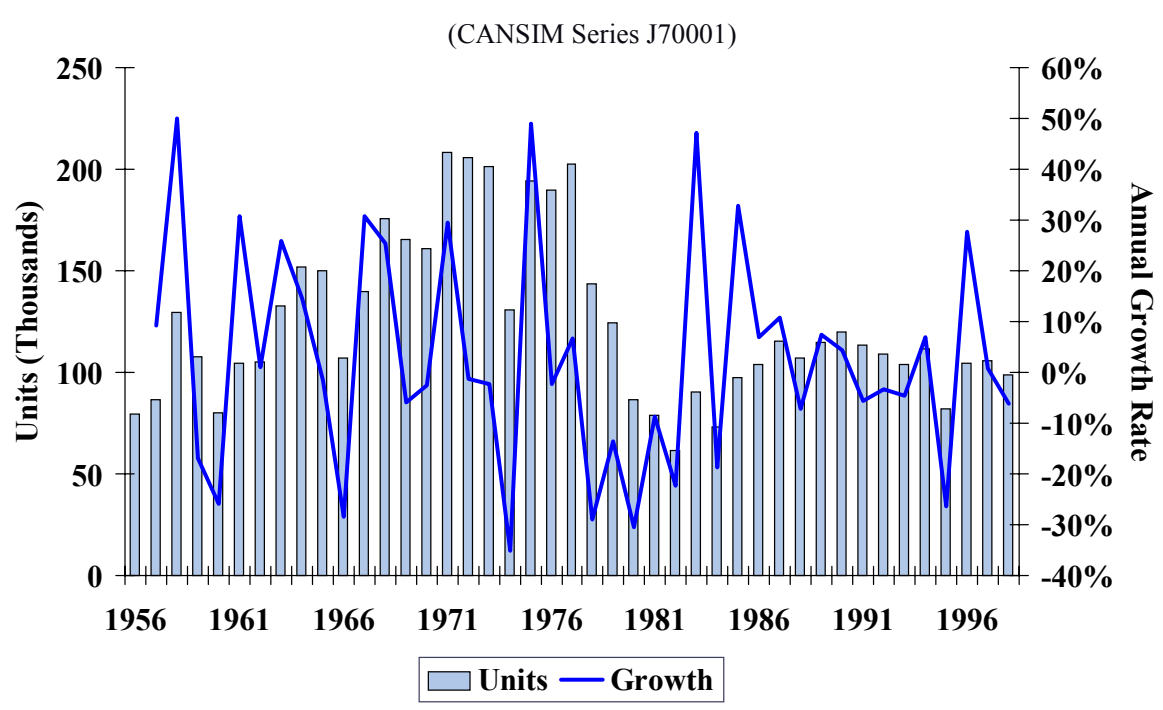

Table 13

Canadian Housing Starts, 1948 to 2000

(CANSIM Series J15001)

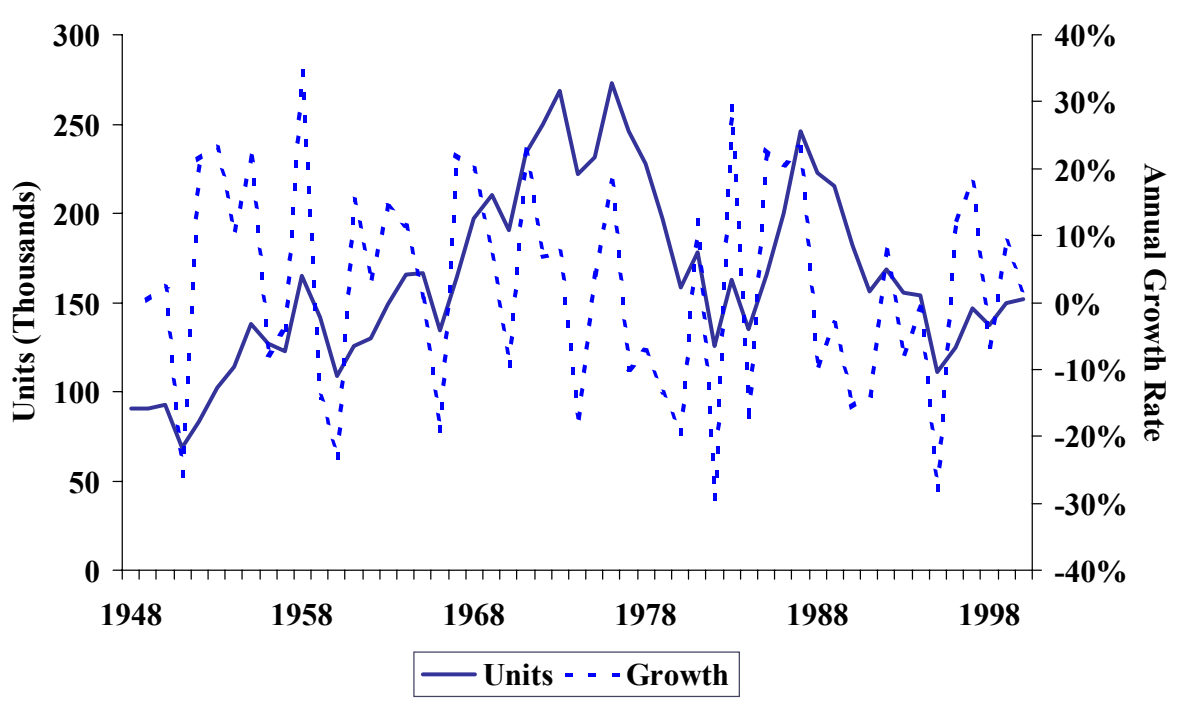

The average loan size increased (CMHC, 2000b) from $\$ 75,229$ in 1989 to $\$ 96,670$ in 1999 , a rate of 2.5 percent per annum, with those for new homes, which account for approximately 17 percent of total mortgages approved, increasing at a faster rate than for existing homes. Further, more homeowners are relying on financing to fund acquisitions; e.g., 
the ratio of units approved for a mortgage to housing starts rose from 52.7 percent in 1989 to 76.7 percent in 1999 (CMHC, 200b).

The principal types of residential mortgages loans in Canada (similar to those in the U.S.) are uninsured conventional loans, privately insured conventional loans and government insured (NHA) loans. NHA loans are made by approved private lending institutions and insured by the Federal government through CMHC. A minor number of NHA loans are also made directly by $\mathrm{CMHC}$ in areas where the private institutions do not or cannot lend, and under special programs for low- and moderate-income households. All three types of loans are made on new construction, existing property and on dwellings for owner occupancy and rental.

\section{B. Demographics}

Population size and composition obviously affect housing and mortgage demand. We provide only limited information for both countries on the demographics. Typically, the housing services consumption pattern follows a life cycle pattern. Young adults from their early twenties until their early thirties, generally speaking, rent in a multiple-unit residential building as they complete studies, save for a downpayment and form couples. A single-family home is then typically acquired for family expansion. Mobility, changes in income, and changes in the size of family dictate housing needs after the original purchase. Finally, at retirement, the adult will usually move back to a multiple-unit residential building. This life cycle implies patterns in house buying and in mortgage needs. While attempts were made in Canada to specifically target potential homebuyers through tax subsidy programs such as RHOSP, there is no fundamental difference in the life cycle patterns across the two countries that would imply differences in homeownership choices.

\section{United States}

The U.S. experienced the typical baby boom pattern after World War II. We illustrate this in Table 14 below. The post-War birth peak was reached in the U.S. in about 1959, with a subsequent "echo" peak in 1989. 


\section{Table 14}

Births in the United States, 1946-1999

(Source: U.S. Census)

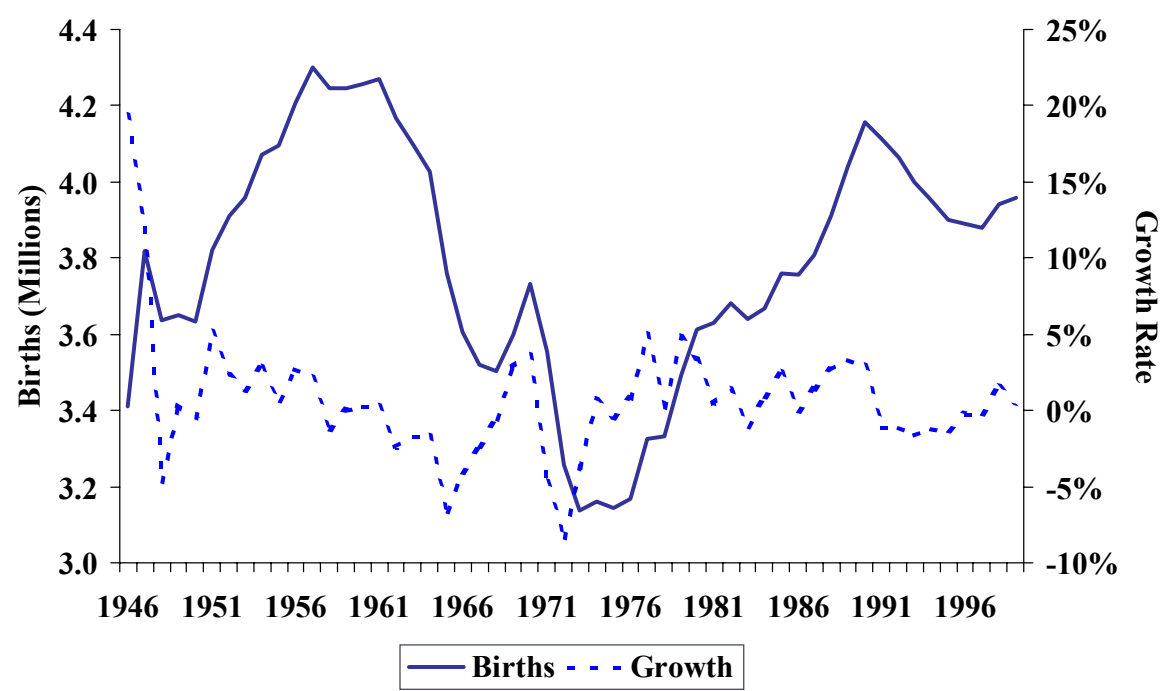

The baby boom statistics, combined with the life cycle predictions for housing demands led to steady increases in homeownership over the 1980s and early 1990s. Most baby boomers that choose to or can afford to become homeowners have entered the ranks of homeownership by now.

Also leading to housing demand increases are the steady rises in immigration in the United States. Table 15 provides that graph. There is fairly steady growth in the immigration population in the U.S. in the post-War period, with a particularly large spike (since diminished) in the late 1980s. Both the birth and immigration data combine to indicate additional demands for housing over the coming decade. 
Table 15

\section{Immigrant Arrivals in the United States, 1940-2000}

(Source: U.S. Census)

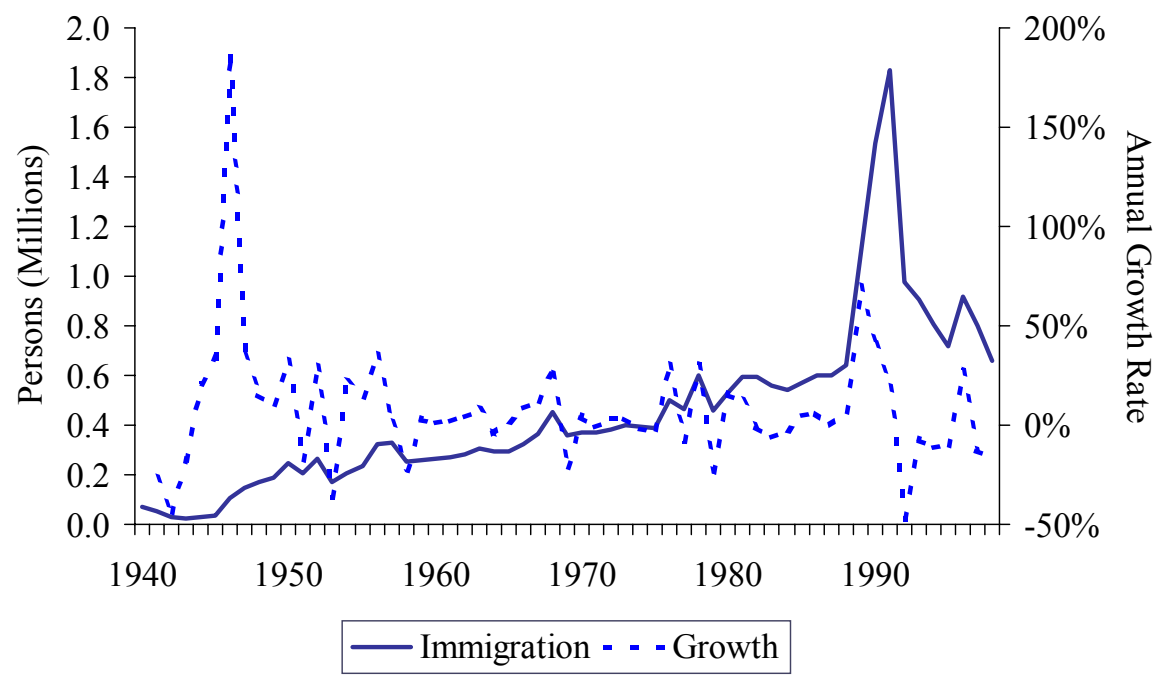

\section{Canada}

After the Second World War, Canada experienced, like the U.S., a rapid rise in the number of births from an increase in fertility rates: the so-called "baby boom". The peak in Canada was also reached in 1959. At the end of the 1980s the baby boom cohort reached its peak fertility years, which resulted in a temporary increase in births: the "demographic echo", but births have continued to decline since then (see Table 16). 
Table 16

Births in Canada, 1946 to 2000

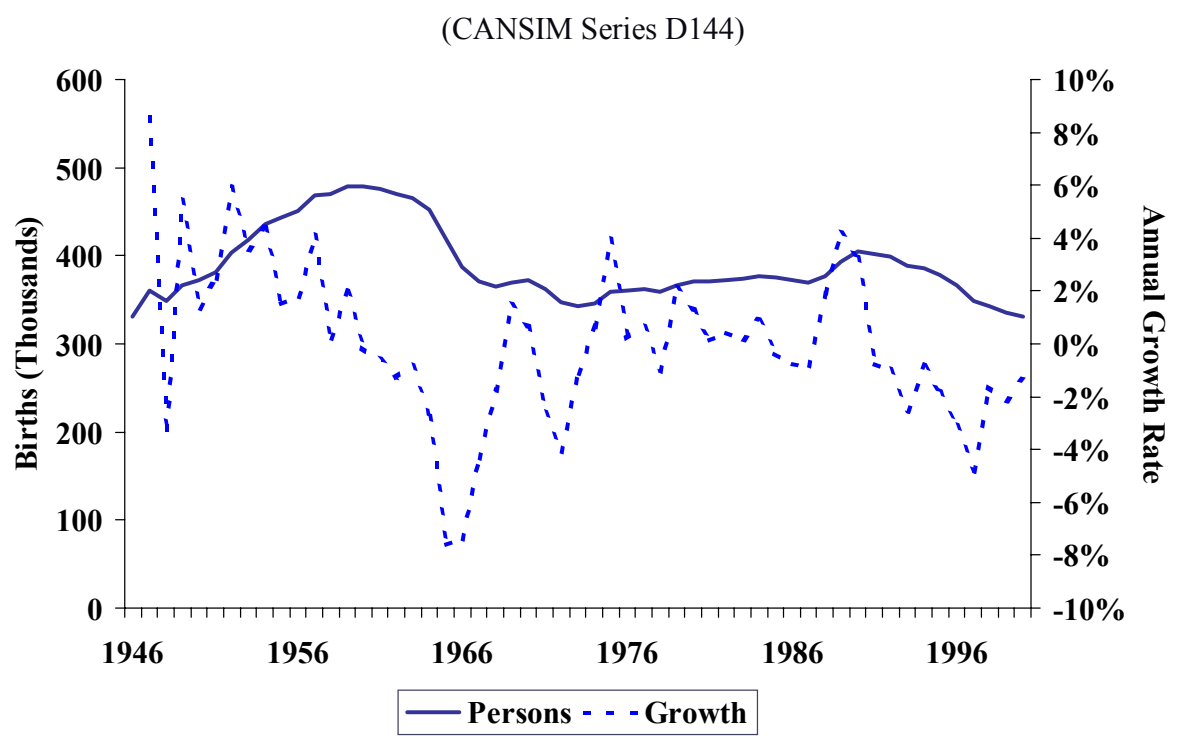

These features suggest that the early baby boomers hit the multiple-unit rental market in the 1970s with a maximum effect near 1980. The full effect on the homeowner housing market was reached towards 1990. The aging of the baby bust generation suggests a large decline in the number of new households likely to purchase homes, while the aging of the baby boomers suggest that a large number are likely to dispose of their homes in favor of multiple-unit living over the next twenty to thirty years. Some forecast (e.g., Foot and Stoffman, 1999 and Mankiw and Weil, 1989) that these changes are likely to lead to dire consequences for the housing (and ipso facto mortgage) market. However, others (e.g., Fortin and Leclerc, 1999) argue that, though demographic composition is important, other factors, such as housing use costs, real household income and housing stock, will moderate the impact of these demographic composition changes.

Two other market characteristics are also important: the move to more households headed by a single adult and immigration. In 1996, the last compiled Census in Canada, an estimate of 14.5 percent of families are headed by a single parent compared to 13 percent at the previous 1991 Census. Immigration in Canada was generally high during the 1950s; see Table 17. Of interest is the large amount of volatility in the immigrant statistics, compared to the fairly steady growth in the U.S. (except for the early 1990s). 


\section{Table 17}

Immigrant Arrivals in Canada, 1940 to 2000

(CANSIM Series X100577, D55 \& D74)

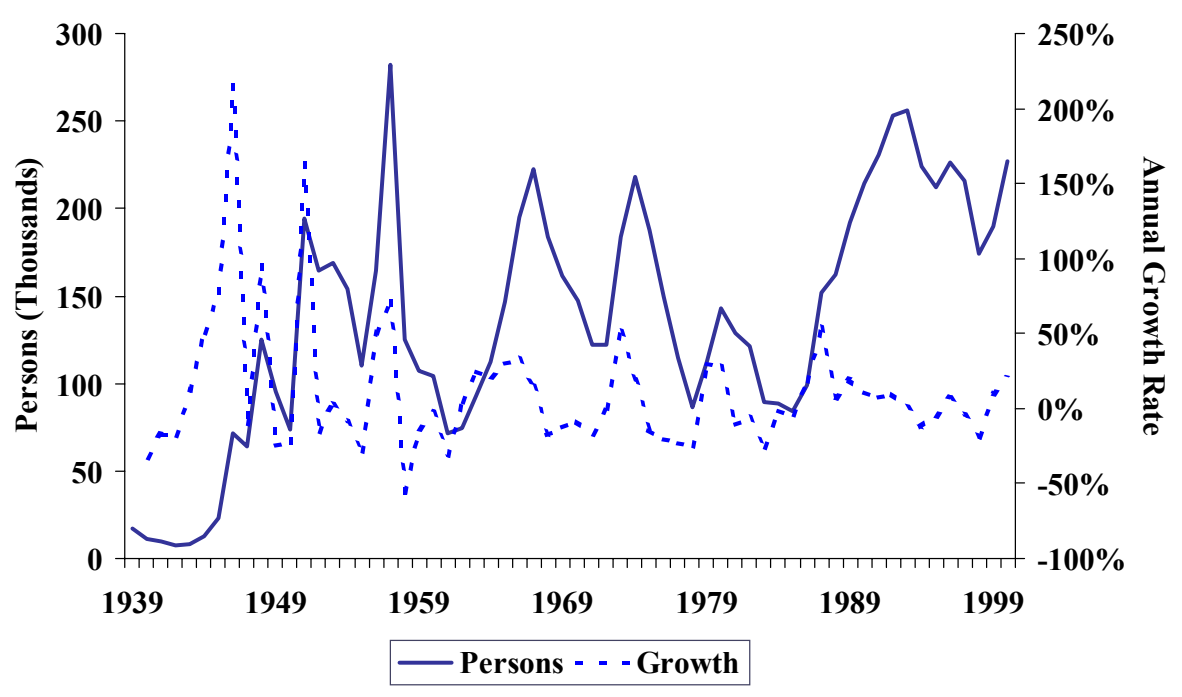

There is no particularly unusual pattern in the birth or immigration statistics that would give rise to the significantly different systems of mortgage finance. The baby boom and echo pattern occur in both countries. Immigration, while more volatile in Canada, was not a large enough factor to have impacted the overall system of mortgage finance.

\section{The Housing Sector and the Economy}

If the differences in housing finance systems cannot be explained by looking at differences in the demographic patterns of the two countries, it might, at least in part, be explained by differences in the role of the housing sector in the overall economy. Housing starts are one indicator of mortgage market activity as new homes, the main source of growth in the housing stock, are largely financed through loans. The housing sector has been characterized by cyclical instability since the Second World War, though the pattern has generally shifted form being counter-cyclical to pro-cyclical, most likely due to the initiatives undertaken to integrate the mortgage market with the overall capital market. 


\section{United States}

Table 18

U.S. Housing Starts, 1959-2000

(U.S. Census Bureau)

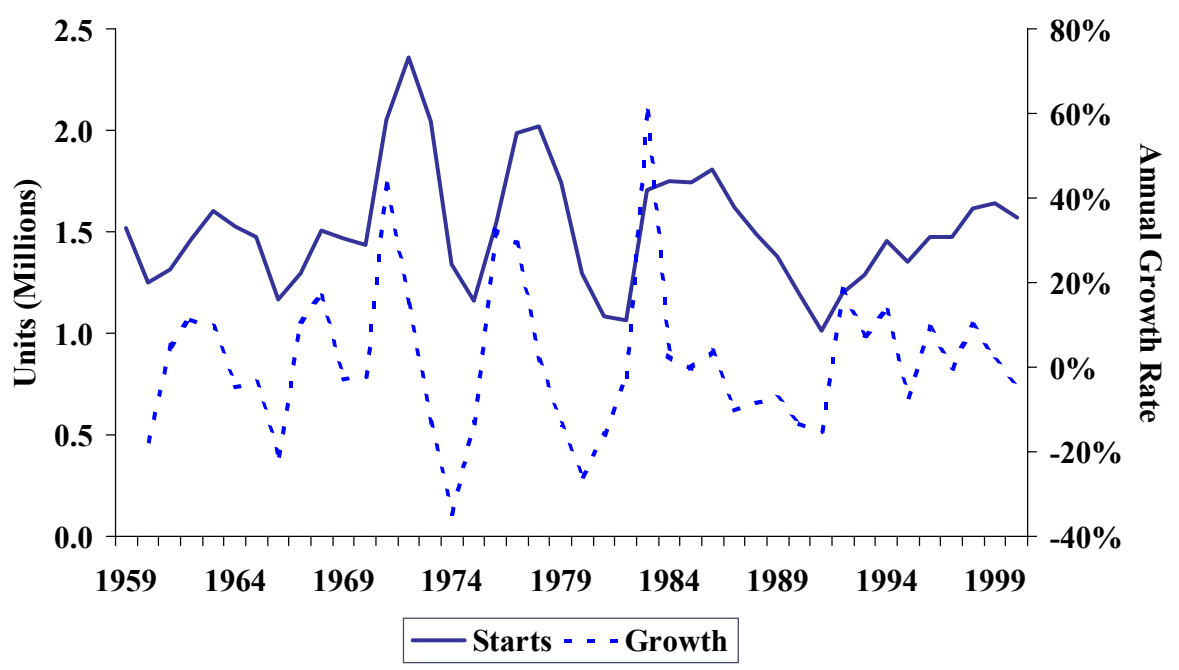

In the U.S., the volume of new residential construction peaked in the early 70 s, but has been cyclical since that time. Starts reached another local peak in 1986, with starts declining over the last half of the 1980s, and have steadily grown throughout the 1990s, a period of exceptional robustness in U.S. financial markets. Even with this robustness, however, housing starts did not surpass their peaks in earlier cycles. In the past year, housing starts have fallen off their recent high.

\section{Canada}

The volume of new residential construction activity in Canada rose rapidly following the Second World War, with the activity peaking in the mid-1970s, but has declined since then, despite a temporary rise in the middle to late 1980s that peaked in 1987 (slightly behind the U.S. peak). Starts stayed at lower levels throughout the 1990s, with negative growth in most years, barely reaching a positive growth rate by the end of the decade; see Table 19 for housing starts in Canada and Table 20 for investment in housing in Canada. 


\section{Table 19}

Canadian Housing Starts, 1948 to 2000

(CANSIM Series J15001)

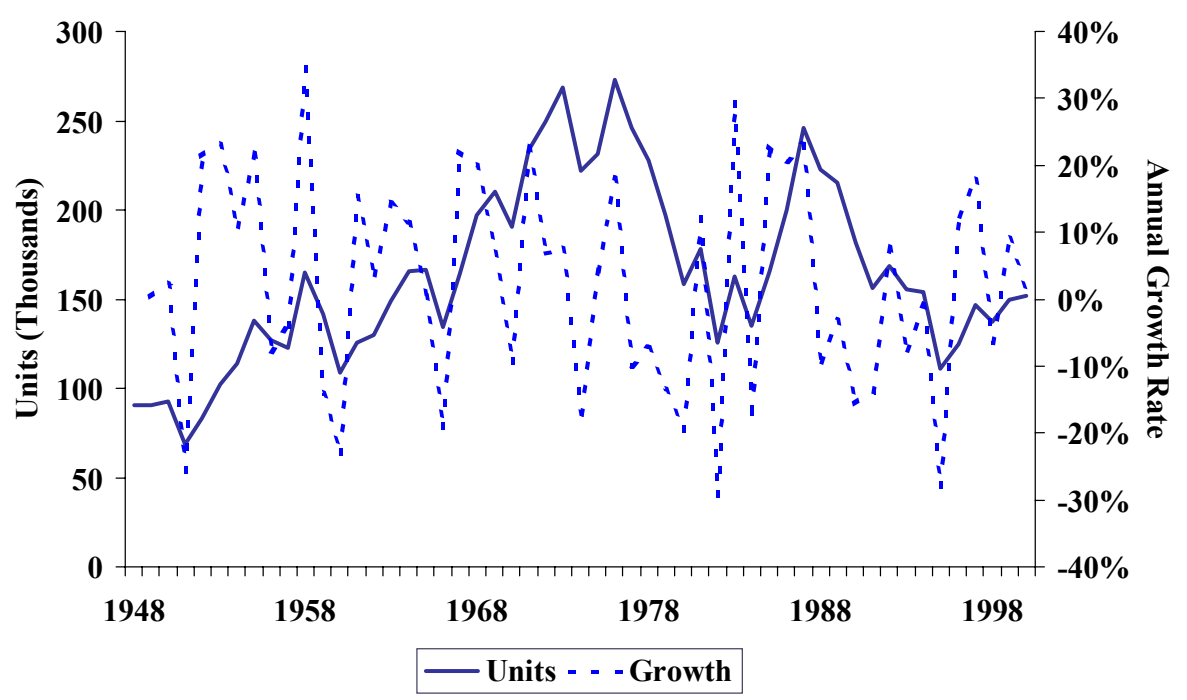

Table 20

Investment in Housing, Canada: 1951 to 2000

(CANSIM Series D847436 \& D847443)

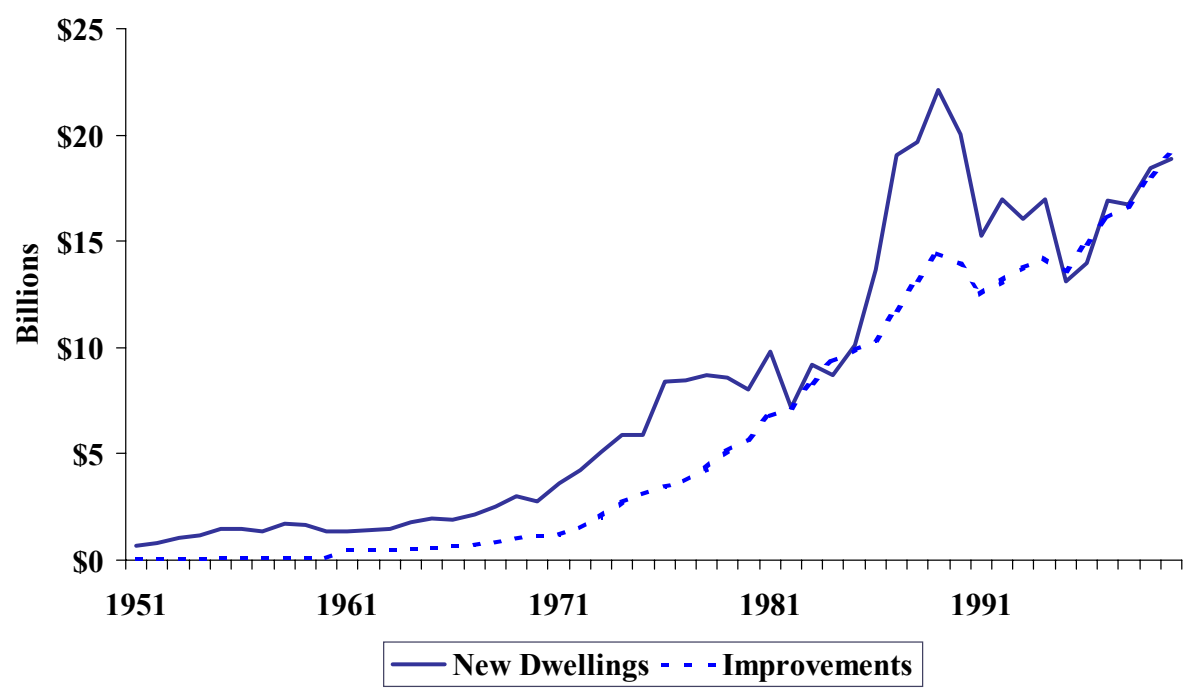

The cyclical volatility in housing starts is evident from the volatile swings in the growth rate series. While cyclical volatility is seen elsewhere in the economy, it has been much more evident in the housing industry, due largely to the reliance of that sector on borrowed funds and, hence, on the fluctuations in interest rates. The decline in new housing production in Canada in 
the decade after the mid-1970s resulted from earlier overbuilding, the volatile interest rates of the 1980s, the 1981-82 recession and the aging of early baby boomers. The rise in Canadian new housing production in the mid to late 1980s largely arose from a backlog in demand (CMHC, 1988).

The level of renovation activity on the stock of existing homes will also influence mortgage market activity, as many renovators take out home equity for home improvements. A strong upward trend in renovation began in the 1970s in Canada; see Table 21. The increased spending on home improvements accounts for a growing share of total residential construction expenditures since the mid-1970s. The share has generally been well over 50 percent since the early 1980s and is likely to continue as the baby boomers move into their 40s and 50s, an age group that traditionally renovate rather than move and reside in housing stock that is also aging. Typically, renovation spending has shown much less cyclical volatility than new construction.

Table 21

\section{Renovations Investment on Residences, Canada: 1961 to 2000}

(CANSIM Series D847303 \& D22977)

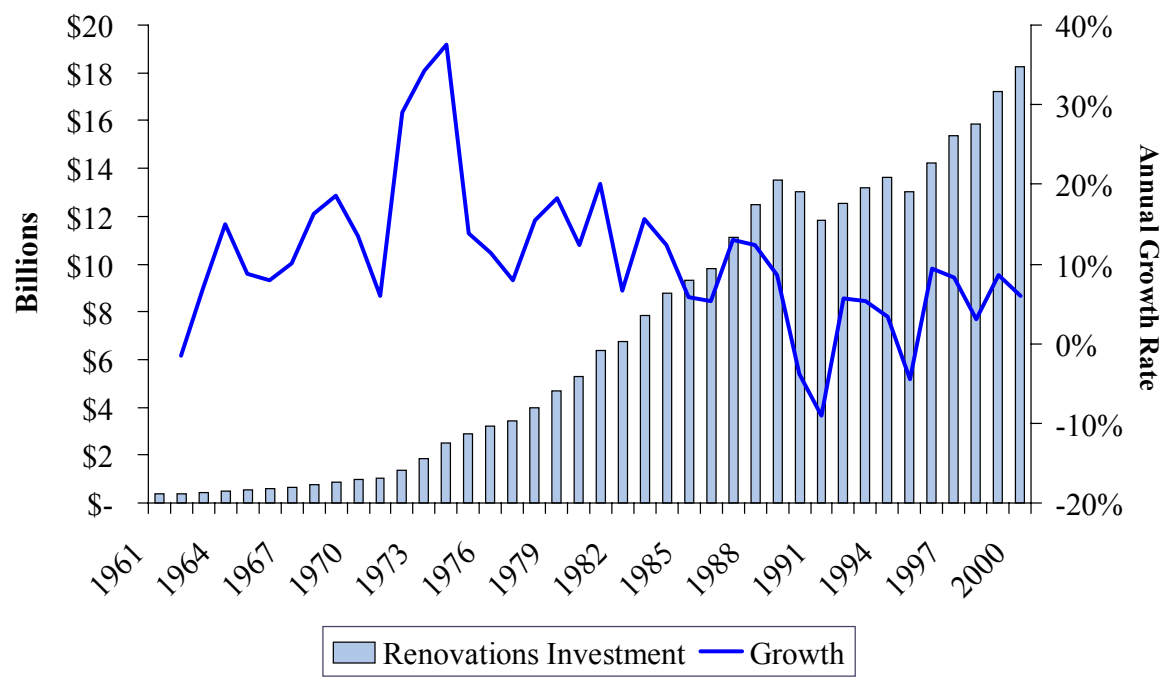

The housing sector has been an important contributor to economic growth in periods with strong demand and strong demographic pressures, while its importance lessens at other times. The percent of Canadian real GDP arising from real expenditures on residential structures from 1926 to 2000 was provided earlier in Table 9. As shown in that Table, the share rapidly declined to the 1940s, but accelerated quickly from the mid 1940s with the boom in construction that followed the war, reaching an all-time peak of 7.7 percent in 1955 . The share fluctuated between 5.5 and 6.7 percent over the $1960 \mathrm{~s}$ and $1970 \mathrm{~s}$, but since then has fallen to between 4.4 and 6.4 percent aside for the boom years of 1987 to 1989 .

The strength of the housing sector is also reflected in house price changes. The real housing price has evolved in a very different manner than in the U.S. Canadian prices experienced strong growth in the early to mid 1970s, while this growth was reflected at a later period in the U.S. (Engelhardt and Poterba, 1991). The U.S. series for average house prices is 
provided in Table 22. While real average house prices have increased fairly steadily (peaking in 1989 and then falling, finally recapturing the previous level by 1999) over the past three decades, the growth rate fell dramatically in the late 1980s, after a peak rate of 10 percent in 1987, resuming strength in the past seven years, with a local peak at 7 percent in 1999.

Table 22

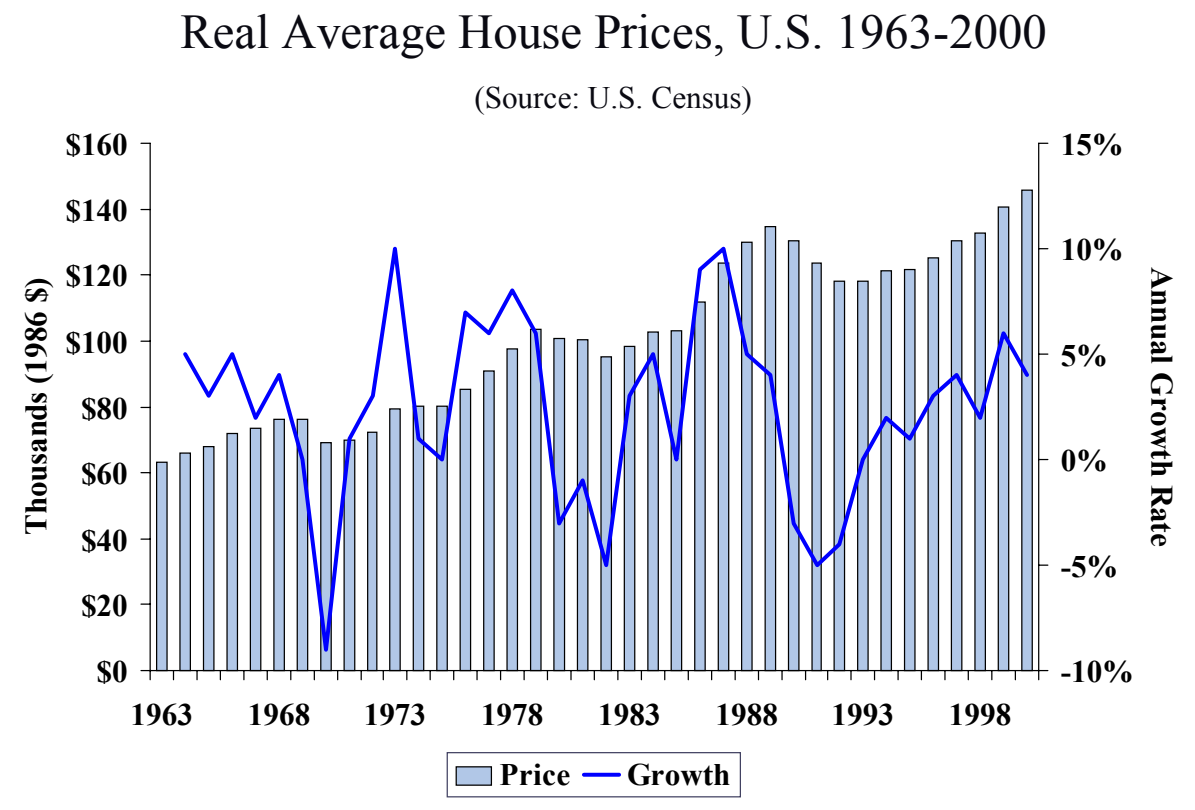

There are various sources for Canadian data on housing prices: average Multiple Listing Service (MLS) sales price, complied by the Canadian Real Estate Association; three indices compiled by Statistics Canada - the New Housing Price Index, the Residential Building Construction Price Index, and the housing cost components in the Consumer Price Index; and CMHC, from the early 1950s until 1985, published the average sales price of NHA housing. The MLS series, which is based on a record of the real estate transactions concluded in the nation's different cities, is the longest. Approximately 90 percent of the sales are residences. The data overestimates the average increase in the real housing price, as changes in the average quality of housing is not taken into account. Nevertheless, given its length, we provide this series and its growth in Table 23. ${ }^{19}$ The real housing price is subject to strong annual fluctuations; e.g., between 1972 and 1974 the real housing price rose by 29.3 percent, between 1985 and 1989 it rose by over 50 percent, while it fell by over 19 percent between 1985 and 1981 and by over 9 percent between 1992 and 1989.

\footnotetext{
${ }^{19}$ The data are from Fortin and Leclerc (1999). The Consumer Price Index has been used as the price deflator.
} 


\section{Real Average MLS Sales Price, Canada}

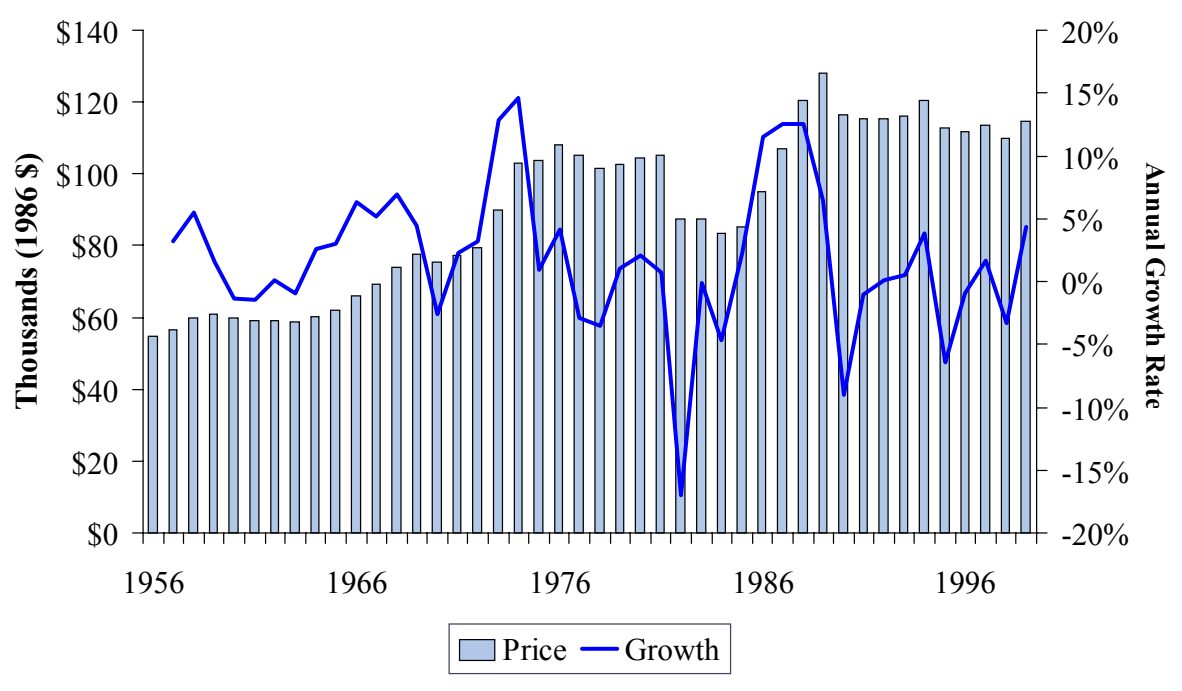

The future prospects for real house prices in Canada are uncertain. Some (e.g., Foot and Stoffman, 1999; Mankiw and Weil, 1989) predict large future declines in real house prices, arising from the aging of the baby boomers and the baby bust generations, and the associated impact this will have on housing demand. Others (e.g., Engelhardt and Poterba, 1991;

Hendershott, 1991; Pitkin and Myers, 1994; Fortin and Leclerc, 1999, amongst others) argue that such studies ignore many other important effects, as well as criticisms on the statistical work, so that the aging of the baby boomers and baby bust generation is unlikely to lead to substantial changes in demand and to real housing prices.

The volatility and the cyclicality of the housing price and housing expenditure data again provide no strong reason for finding the completely different system of mortgage finance. The very large real price increases but, at least temporarily, have persuaded some borrowers that the capital gains more than made up for bearing interest rate risk, but this is not an explanation that would persuade many economists.

\section{Mortgage Loan Arrangements}

\section{United States and Canada}

\section{A. Mortgage Rates}

One of the most striking differences between Canada and the U.S. are the large differences observed in product types and in terms on mortgage loans. The U.S. typical mortgage instrument is a thirty year fixed rate mortgage (FRM) with a fairly low spread to Treasury. 
While adjustable rate mortgages (ARMs) are available, they are rarely the first choice of homeowners, unless the borrowers anticipate a short term refinancing. In the U.S., rates increase with fixity of term, but the spread between one year ARMs and 30 year fixed rates are not great. For 2001, the 30 year FRM/1 year ARM spread ranged from 21 to a high of 148 basis points, making the fixed rate the choice for most consumers. Spreads and rates are provided in Table 24 below.

\section{Table 24}

\section{Comparison of Monthly US Conventional Mortgage Rates \& Selected} US Treasury Rates

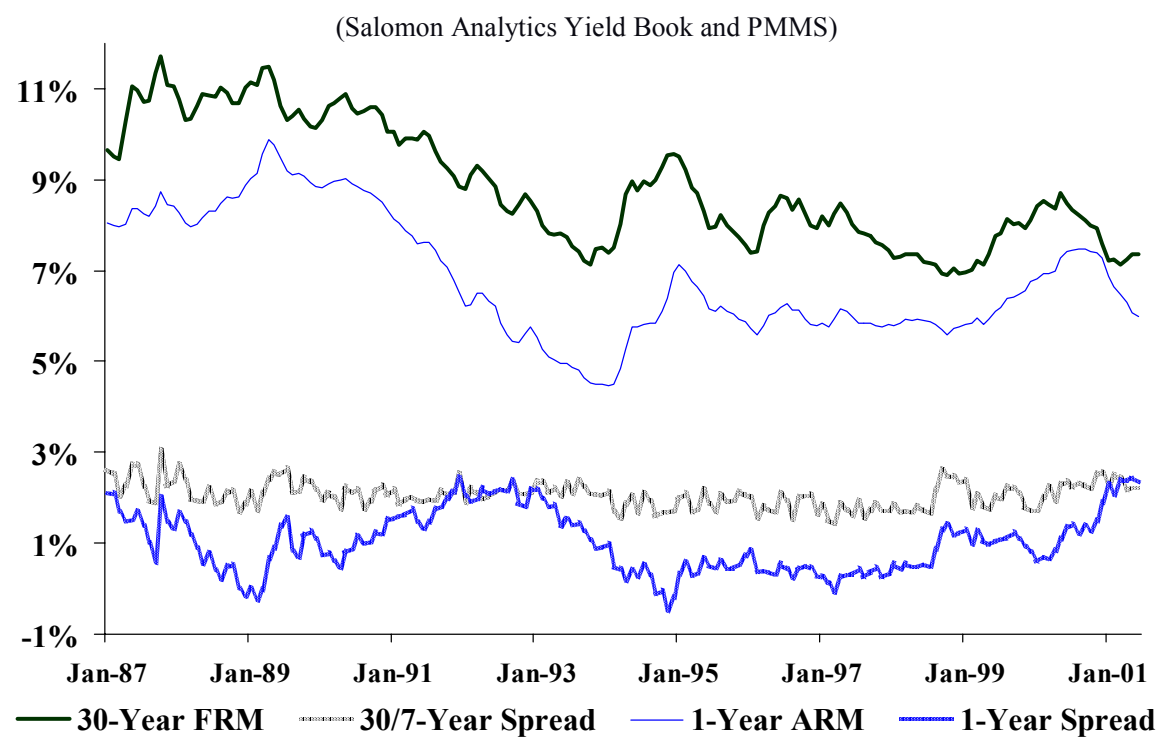

The four main types of mortgages offered by lenders in Canada are closed, open, fixed, and variable rate with the majority of Canadian borrowers selecting closed short-term fixed-rate mortgages. That is, the main form of mortgage adopted by Canadians is a rollover mortgage, with interest rates fixed for the term of the agreement, and the loan is then rolled over for another term. Amortization periods range from 10 to 30 years, with 20 to 25 years being the most common; ceteris paribus, borrowers have an incentive to choose the shortest possible amortization period $^{20}$.

Despite the dominance of only a few chartered banks in the Canadian mortgage market, there is some competition among lenders as evidenced by the spread between posted mortgage rates and the costs of funding mortgages approximated by yields on comparable Government of Canada securities. Table 25 compares the 1-year and 5-year posted conventional mortgage rates with the 1-year Treasury Bill rate and the 5-year Government of Canada bond yield from January 1987 to May 2001. The maximum 1-year spread is 2.5 percentage points with a median spread of 1.3 percentage points, while the maximum 5 -year spread is 2.9 percentage points with a median spread of 1.9 percentage points.

\footnotetext{
${ }^{20}$ Breslow et al. (1996) examine the joint decision of term and amortization by cost minimizing risk averse borrowers using 1980 to 1988 Canadian data.
} 


\section{Table 25}

\section{Comparison of Monthly Canadian Conventional Mortgage Rates \& Selected Govt of Canada Rates \\ (CANSIM Series B14069, B14075, B14024 \& B14050)}

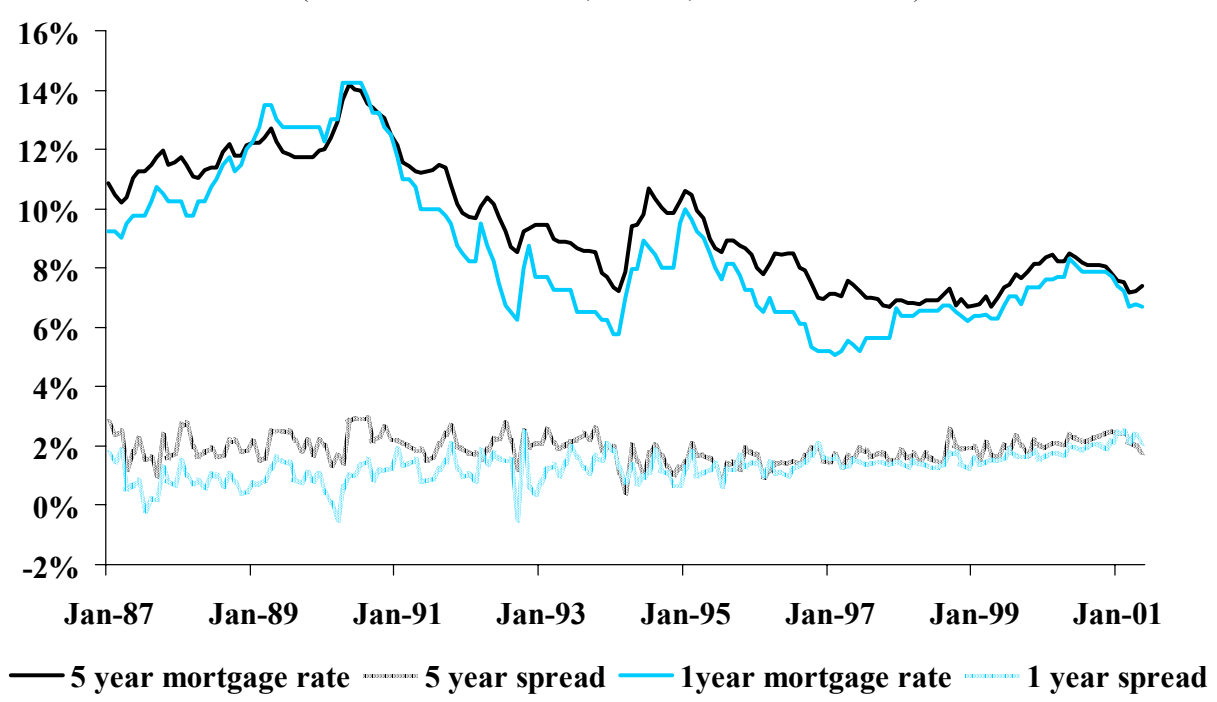

A closed mortgage keeps payments unchanged for the loan duration, typically five-years for the majority of Canadians though 7, 10, 15 and 20-year terms are becoming slightly more common and short terms of six months, 1-year and 3-year are also possible options. The interest rate generally rises with the length of term. A closed mortgage has the benefit of payment stability but there are often significant prepayment penalties in Canada, should the borrower wish to terminate the contract. An open mortgage allows the flexibility of prepayment, with an interest rate cost associated with this freedom. Table 26 (at the end of the paper) illustrates the interest rate spread between closed and open mortgages in Canada for terms of 6 months and 1year as at August 2, 2000 and June 1,2001 for ten Canadian financial institutions. The penalty is severe even for a 6-month mortgage, at 45 basis points, and more severe for the 1-year term with a spread of 80 basis points dominating so that, for example, the additional cost in interest for a 1year term loan of $\$ 150,000$ is $\$ 1,200$.

A variable- (or adjustable-) rate mortgage offers the advantage of lower rates when mortgage rates decline, but exposes the borrower to interest rate risk should increases occur, resulting in higher payments or an increase in the interest share of a fixed payment. In the current economic environment, the posted variable rates are typically well below those for fixedrate mortgages. Table 27, which compares the closed variable rates for seven Canadian institutions with the closed fixed-rates for terms of 6 months to 5-years, shows that Canadians could be making significant savings on interest charges by choosing a variable rate. However, many Canadians are risk averse, continuing to choose fixed-rate mortgages ${ }^{21}$, despite public

\footnotetext{
${ }^{21}$ Long-term mortgages have a life span of five-years or more. CMHC (2000a) reports that first-time homebuyers tend to be more cautious than those borrowers who have carried previous mortgages; this may reflect a lack of experience, but may also be a sign of high financial commitment by first-time buyers, who may be unable to risk higher payments that may result when interest rates rise as may happen with a variable rate mortgage. Further,
} 
press on this issue. For example, Garth Turner, a well-known Canadian investment advisor, advocates in his May 2001 column (Turner, 2001) "So, in response to the question of what is the proper borrowing strategy, I don't think there is any question at all - go variable"; and another advisor, Gordon Pape, in one of his May 2001 Canadian Broadcast Commission reports, states "People always ask me whether they should go short or long term on their mortgage. My answer is always the same - pay the least interest you can".

Canadians have not always been able to choose from such a range of terms.

Terms of 25-years were the norm (and required for NHA loans with mortgage insurance) prior to the interest rate rises in the latter half of the 1960s. The concerned lenders, recognizing potential losses from interest rate rises and an imbalance between mortgage loan terms and their liability offerings that could cause capital squeezes in such volatile rate times, switched to a 5 -year term for conventional mortgages, and CMHC followed in 1969 for NHA loans. By 1970, 58 percent of NHA loans, and likely a higher proportion of conventional mortgages, were at the shorter term (Unger, 1977). When rates soared even higher during the 1970s, terms offered were even more limiting, sometimes as short as 3 months. Again, $\mathrm{CMHC}$ followed the market and extended NHA loans to 3-year terms in 1978, 1-year terms in 1980 and to variable-rate mortgages in 1982. Terms of more than 3-years were unavailable by the beginning of the 1980s (Jones, 1998). This paucity of long-term offerings is one of the motivations that led the government to legislate for CMHC to sell mortgage-backed securities in 1986, which subsequently resulted in longer-term loan offerings that consumers did not readily respond to until the fall in interest rates in the early 1990s. It is likely the move to variable mortgage rates in the early 70 s that prevented any debacle in Canada such as that seen with the thrifts in the U.S. in the 1980s.

\section{B. Prepayment Options}

Prepayment penalties are rarely used in the U.S. prime market. Gates and Kirk (2001) note that over the course of the 1980s, the share of prime mortgages with prepayment penalties dropped from 16 to 9 percent. They also note that prepayment penalties are often found on subprime loans. A working group in the U.S. created by the Mortgage Bankers Association attempted to agree on the parameters of a prepayment penalty product that could be securitized. The model product had a longer penalty period (five years) and a penalty amount of six months interest when prepayments exceeded 20 percent of UPB. Freddie Mac and Fannie Mae ultimately chose not to proceed with the product citing a mismatch between expectations of investors, mortgage originators and borrowers. No such problems exist in Canada.

Prepayment options for Canadians vary with the mortgage package but usually up to only 10 to 20 percent of the original principal balance can be paid off annually without a penalty or an administration fee. A related common feature is the "double-up and skip-a-payment" option, which allows a borrower to "bank" extra mortgage payments that can be used later if needed or used to permanently reduce the principal amount. Some packages also allow the borrower to increase their regular payment by up to 100 percent without penalty. Such options are extremely useful, as Canadian mortgage payments are made with after-tax dollars so that over-payment of interest is expensive. Zorn and Lea's (1989) study of mortgage prepayment behavior in Canada

borrowers have a natural tendency for risk aversion, with more borrowers selecting short-term mortgages as mortgage rates fall and long-term mortgages when there are signs of interest rate hikes. 
supports this hypothesis that the high after-tax cost of mortgage debt, compared with other investment alternatives, makes partial prepayment options important to consumers. Full prepayment in Canada typically results in a three-month interest penalty. Whether a lender applies the three-month interest penalty or waives a penalty altogether varies with lender and with borrower. Note that technically a "closed" mortgage can only be prepaid (i.e., "opened") at the lender's discretion, though this is rarely refused as lenders recognize that mortgage customers are not loyal. CanadaMortgage.com, ${ }^{22}$ provides much information to consumers about available products, including information on the often found prepayment penalties.

In terms of the adjustable nature of the mortgage rates, some short-term mortgage rates in Canada move with the Bank of Canada prime rate while others track Treasury Bills and Government of Canada bond yields. For example, the CIBC "Better Than Prime" package is a five-year variable-rate mortgage (convertible to a three-year fixed-rate mortgage at any time) that floats at a rate of $1.01 \%$ below bank prime for the first nine months and a rate of prime minus a quarter-point for the rest of the term. Other options include capped variable-rate mortgages, introduced in 1993 by several Canadian banks, which aim to allow for the benefit of a variablerate, while preserving an acceptable long-term rate. This rate typically floats at about prime plus 1 percent and is capped at about 0.5 percent above the posted 5 -year rate; e.g., the Royal Bank offers a 5-year "RateCapper Mortgage" whose rate is the Royal's loan base rate plus a premium with a maximum rate set when the mortgage is booked; as at 20 June 2001 the RateCapper rate was 6.75 percent with a maximum of 7.95 percent, which compares to their variable rate offer of 6.25 percent and their closed 5-year fixed-rate of 7.75 percent. Other incentives offered to potential Canadian mortgage customers include frequent flyer points, lines of credit at reduced rates, free fees on accounts and credit cards for periods, contributions to investment accounts ${ }^{23}$, multi-rate/split-term loans, and cash-back deals ${ }^{24}$, though some of these features are rarely used. Multi-rate/split-term mortgages allow borrowers to partially hedge against interest rate rises and partially obtain benefits from lower rates; e.g., TD Bank's "Multi-Rate Mortgage" allows for the loan to be divided into as many as five different parts, each with its own rate, term, amortization period and payment frequency.

In Canada, early renewal typically requires a small administration fee, though no fee is paid when the current posted rate is lower than that under the loan contract, which may result, for example, when a consumer switches from a fixed-rate term mortgage to a variable-rate mortgage. Some Canadian institutions allow "blending and extending" where an increase in the mortgage at current rates is permitted, assuming a satisfactory LTV ratio, so that the "blended rate" is a weighted average of the rate of the existing mortgage and the rate applicable to the

\footnotetext{
${ }^{22}$ The internet site for CM Canada Mortgage Corporation is found at www.canadamortgage.com. The site provides information on mortgage products, promotions and pricing and provides access to mortgage consultants, who are not attached to a particular lender, at no extra fee to customers.

${ }^{23}$ As an illustration, the Royal Bank offers a "First-Time Home Buyers Package" that includes annually for five years, a $\$ 500$ contribution to a Royal Bank investment fund, a financial review and a no fee Visa Gold card, as well as free AOL Canada membership for one year and free chequing for six months.

${ }^{24}$ FirstLine Mortgages, for instance, offer a class of "Loan Closer Mortgages" that provide a percentage of the mortgage back in cash on closing; e.g., their 5 -year $2 \%$ Loan Closer at a rate of $7.65 \%$ gives the borrower $2 \%$ of the mortgaged amount upon closing, while their 7 -year $4 \%$ Loan Closer provides $4 \%$ of the loan back upon closing at a rate of $8.15 \%$. Another institution, Scotiabank, offers up to $3 \%$ of the mortgage amount in cash or up to $3.25 \%$ towards a Scotiabank Registered Retirement Savings Plan (RRSP) for a 5-year or 7-year closed fixed-rate loan.
} 
additional funds requested. Choices on mortgage payment frequencies depend on the institution and the mortgage package with a monthly option always being available and some allowing biweekly, semimonthly or weekly payments to match employment income patterns and to allow one way for borrowers to pay off the mortgage faster.

Canadians have not always faced such a range of options; for example, long-term mortgages of more than five years have only been available since the early 1990s; closed mortgages rarely permitted prepayment or accelerated payment; early renewal was not available and variable rate mortgages were not offered. NHA loans prior to the early 1970s allowed 10 percent of the loan balance to be paid in each of the first two years and full prepayment after 36 regular monthly payments (Poapst, 1975). Table 28 provides further details on the different product features between the 1990s and the 1970s and highlights the greater choices now available to borrowers. Note, though, that many of these packages are not available to those who require mortgage insurance (i.e., those who have less than 25 percent down). Then, the products and terms are somewhat limited: 6 months fixed rate or longer under the regular CMHC program and 3 -year fixed-rate or longer under the 5 percent down program.

It is clear that creativity dominates the competitive offerings in Canada - however, notably, none of the top five banks offer the U.S. equivalent product - a thirty year fixed rate mortgage, with no prepayment penalty, at a rate with only a small spread over Treasury rates. While the range of options is increasing, there is no likelihood that the mortgage offering of choice in Canada will become the same as that offered in the U.S. The Canadian banks have no regulatory or economic incentive to move to a system much more favorable to borrowers.

\section{Reverse Mortgages: Using Home Equity Wealth}

Banks, thrifts and other financial institutions in the U.S. offer reverse mortgages with at least four packages available for consumers to choose from: FHA Home Equity Conversion Mortgage Program (HECM); Fannie Mae's Home Keeper reverse mortgage and companion Home Keeper for Home Purchase product; and the Cash Account Plan, which is a private reverse mortgage offered by Financial Freedom Senior Funding Corporation. The HECM and Home Keeper products are available in every state, while Financial Freedom's product is only offered in a limited number of states.

Canadian borrowers have only a limited reverse mortgage market, unlike the U.S., though legislation has been in place since the early 1980s that enables institutions to offer such loans. A reverse mortgage permits the homeowner to convert home equity into a lump sum of cash, stream of income, a line of credit, or a combination of these, with no repayment required until some pre-specified future date, which normally coincides with the date at which the borrower ceases to occupy their home as their principal residence. The money loaned is tax-free, though its provision may impact on certain types of government assistance, and it can be used for anything: living expenses, home repairs and improvements, health related expenses, education, travel and so on. While a reverse mortgage loan is outstanding, the home's title remains with the borrower. An applicant must be at least 62 to qualify and own the home in question; no medical or income requirements need to be met. Typically, the size of the reverse mortgage is determined by age, type of package desired, home value, and, sometimes the house location and gender of the applicant. 
The Canadian reverse mortgage market started off well in the early 1980s but virtually ceased during the recession. Currently only one product, the Canadian Home Income Plan (CHIP), is available. CHIP is obtainable nationwide, and offered by a private company, Canadian Home Income Plan that began in 1986. The Canadian government, unlike that in the U.S., has not participated in arranging reverse mortgages, despite amendments to the NHA that permits reverse mortgage insurance. Under CHIP the homeowner can access from 10 to 40 percent of the appraised value of the home. The product is offered directly from the company, six major banks (Royal Bank Financial Group, TD Bank, Scotiabank, Bank of Montreal, National Bank and $\mathrm{HSBC}^{25}$ Bank Canada), and from other financial planners, accountants and mortgage brokers. CHIP applicants are also permitted to rent their property out for short periods and the mortgage is portable to another prime residence. As at June 2001, the CHIP had financed more than $\$ 275$ million in reverse mortgages (CHIP, 2001).

\section{Downpayment Requirements and Mortgage Insurance}

In the U.S., conventional mortgages without private mortgage insurance (or in a special program) typically have a maximum LTV of 80 percent. Government loans (FHA, VA, RHS) are insured at time of origination. To see the difference in shares between loan types, we provide Home Mortgage Disclosure Act data in Table 29. In Canada, mortgages with a LTV of 75 percent or less are termed conventional mortgages. A borrower who requires more financing (normally only up to 95 percent) from the lender (a high ratio mortgage) must purchase mortgage insurance, to cover the likely increased risk of default, given the lower owner equity; such loans are termed NHA loans. The National Housing Act of 1954 allowed for the introduction of mortgage insurance by authorizing CMHC to operate a Mortgage Insurance Fund, and the willingness of finance institutions to fund home buying resultantly increased.

These low downpayment requirements have not always been in place - a LTV of 50 percent was the usual requirement in the early 1930s and institutions were unable to lend more than 60 percent (Harris and Ragonetti, 1998). In 1935, the DHA allowed for up to 80 percent LTV with 20 percent from the state and 60 percent from private lenders, and this program was extended in the first 1938 National Housing Act. Nevertheless, few such loans resulted and by the late 1940s LTVs for most conventional loans had only risen to 66 percent. This conservative lending policy remained in place until the introduction of mortgage insurance by the CMHC in 1954. This contrasts to U.S. practice, where downpayments of 90 percent were permitted by the late 1940s after the introduction of loan insurance by the FHA in 1934; prior to that date LTVs of 50 percent were the norm in the U.S. (Harris and Ragonetti, 1998). So, Canadian homeowners were expected to invest more equity than their American counterparts from the late 1920 s to mid-1950s.

Two types of mortgage insurance are available to Canadian borrowers: the government agency insurance through $\mathrm{CMHC}$, and the private insurance available through the General Electric Mortgage Insurance Company of Canada (GEMICO) ${ }^{26}$. The LTV ratio can increase to as much as 95 percent once mortgage insurance is acquired, which significantly

\footnotetext{
${ }^{25}$ The Hongkong and Shanghai Banking Corporation.

${ }^{26}$ The company is made up of Canadian mortgage finance professionals and is regulated by the Office of the Superintendent of Financial Institutions.
} 
lowers the downpayment required for homebuyers. Recently, one Canadian bank, Scotiabank, added a minimum 5-year term package that requires no downpayment, subject to a family income of more than $\$ 70,000$ per annum, positive net worth and a "good" credit rating. ${ }^{27}$ The one-time portable ${ }^{28}$ insurance premium, which can be paid separately or added to the mortgage without affecting the LTV, is 3.75 percent of the loan amount if the downpayment is less than 10 percent, 2.5 percent when the downpayment is less than 15 percent, 2 percent when the downpayment is less than 15 percent and 1.25 percent for a downpayment less than 25 percent; GEMICO requires a significantly larger insurance premium of 6.5 percent for the Scotiabank "No Downpayment Mortgage". In the U.S. conventional market, the mortgage insurance premium is 32 basis points ( 0.32 percent) for LTVs from $80-85$ percent, 52 basis points for greater than 85 percent through 90 percent, 78 basis points for LTVs greater than 90 percent and up to 95 percent and 96 basis points for the highest LTV category (greater than 95 percent LTV).

\section{E. Summary: Distribution of Risks}

There are three basic risks in mortgage lending: prepayment risk, interest rate risk, and default risk. Lenders in the U.S. potentially face substantial prepayment risk, as borrowers typically take out 30-year term fixed-rate mortgages. However, there are few, if any, redemption penalties because the dominant use of the secondary market in the U.S. means that the prepayment risk is effectively priced into the MBS and hence is "mutualized" among all borrowers (Coles and Hardt, 2000). In contrast, Canadian borrowers typically face stiff prepayment limitations and penalties. Some "open" mortgages that allow for full prepayment without penalty face a significant interest rate premium and full prepayment of a "closed" mortgage may result in a charge of up to three months interest. When loan terms were 25-years or more prior to the 1970 s, Canadians were able, under the Federal Interest Act, to fully prepay once every five years without penalty. However, once short-term loans became the norm during the 1970s most conventional loans included no prepayment options, though this could be done at the end of the (short-) term period. Options for prepaying within term finally appeared during the 1980s (Jones, 1998).

Note, though, that up front "points" are rarely charged in Canada, unlike the U.S., which partially explains the differences in prepayment practices between the two countries. Such "point" systems effectively act as a prepayment penalty that declines with loan life. Whether prepayment penalties, or their absence, affects homeowner behavior is uncertain. Green and LaCour-Little (1999) suggest that household demographic characteristics (including house price) may partially explain the seemingly irrational borrower prepayment behavior in the U.S. Green and Shoven (1986) suggest that the important determinant of prepayment is related to household mobility rather than due to interest rate issues (or, presumably, prepayment penalties), though Quigley (1987) argues that such transaction costs can exert an impact on mobility and hence on the likelihood of prepayment; see also Peristiani et al. (1997), Archer et

\footnotetext{
${ }^{27}$ To qualify for mortgage insurance the house must be in Canada and considered the principal residence; the homerelated expenses must not exceed 32 percent of the gross household income; the total monthly debt load must not exceed 40 percent of the gross monthly household income; the borrower must be able to pay closing costs equivalent to at least 1.5 percent of the purchase price; and the home price must be within the eligibility ceiling for the particular area, which is currently $\$ 250,000$ in Toronto, Vancouver and Victoria, $\$ 195,000$ for 22 other centers plus all North-Eastern Ontario centers, and $\$ 125,000$ for the rest of Canada.

${ }^{28}$ Portable across lender and house, though the latter requires that the mortgage be originated after April 1, 1996.
} 
al. (1996), Bennett et al. (2000), Deng et al. (2000) LaCour-Little (1999), Yang et al. (1998) among others on this issue. Note that there is little empirical research on this issue with respect to Canadian borrowers. Zorn and Lea (1989) show that Canadian partial prepayment is sensitive to the differential between the rates of return on housing and on other assets; Jones $(1994,1995)$ examines the extent to which Canadian households hold excess mortgage debt so that other nonhousing household objectives can be met; and Jones (1998) asserts that the likelihood of prepayment is sensitive to the spread between the contract rate and the current posted rate and that the overall prepayment rate is higher in the U.S. than in Canada.

Mortgages are terminated not only through prepayment but also when the borrower defaults. The brunt of the default risk in Canada is borne by the borrower, as Canadians are required to pay default mortgage insurance when their downpayment is less than 75 percent, so that lenders do not face a higher risk of default with high ratio mortgages. This improves access to funds for home buying, as lenders are willing to finance low downpayment borrowers. No insurance is usually required when the downpayment is more than 75 percent, as the higher equity invested typically implies a lower default probability. Defaults in Canada tend to vary by region, which Jones (1993) suggests arises in part from differences in enforceability of personal covenants in mortgage loans; e.g., lenders in British Columbia do successfully enforce actions whereas Alberta law prohibits enforcements of personal covenants.

Borrowers in the U.S. have many choices available to help them cover for possible interest rate rises, while borrowers in Canada have limited offerings that generally force most of the cost of rises in interest rates onto the borrower rather than the lender. Risks associated with fluctuating mortgage rates can be reduced by increasing the term or the amortization period. In Canada 25-year terms were the norm prior to the latter half of the 1960s when institutions began offering only 5-year terms because of their increased exposure to interest rate risk with the rate rises during that period. The shorter term more closely matched the lender's liabilities pattern, and so assisted in them meeting capital requirements. Jones (1998) also advocates that the change in term conditions likely assisted in reducing housing starts volatility. In 1969 CMHC followed the market for conventional loans by moving NHA loans to 5 -year terms rather than the previous 25-year terms. The further hikes in interest rates over the 1970s resulted in even shorter terms being offered (as short as 3-months) as well as the introduction of variable-rate mortgages so shifting interest rate risks virtually completely to borrowers. During these inflationary periods with high nominal interest rates, the real value of mortgage payments is "tilted" toward the early part of the repayments schedule, which reduces the borrower's ability to maintain a given payment schedule. The real payment tilt burden led to a rise in defaults in Canada as well as the introduction of some government assistance programs to assist homeowners meet their payment schedules (described above).

\section{Securitization \& Secondary Mortgage Markets}

Securitization involves the packaging together of bundles of mortgages and their resale, which can then be traded on the capital markets analogously to other assets. This unbundling of the mortgage process enables institutions to concentrate on particular activities rather than needing to fully cover all functions: mortgage package design; selling or marketing of the loan; packaging the loan; administration; funding; the assumption of risk; default and delinquency management. This can lead to efficiency gains that may result in lower mortgage funding costs, more capital available for mortgages, mortgages with longer terms, and additional capital for 
residential construction. Securitization and secondary mortgage markets are expanding rapidly worldwide in both the private and public sectors with at least 18 countries issuing mortgagebacked securities (MBS); Lea (2000). The advantages of securitization include: efficient use of capital as risk is sold off to third parties; higher liquidity as the loan financer does not need to have sufficient funds for the lifetime of the loan; superior risk management as riskier loans can be sold off and changes can easily be made to the loan portfolio if the risk profile alters; reduced cost of capital; increased availability of capital via access to capital markets; and reduced transactions costs from efficiencies in intermediation; e.g., see Lea (2000).

There exist vast differences between the evolutions of the U.S. and Canadian secondary mortgage markets. The U.S. growth in securitization arose from the credit crisis in the savings and loans associations ("thrifts") during the 1980s period of rapidly rising and unstable interest rates. The thrifts were funding long-term fixed-rate mortgage loans from variable rate deposits, which did not cause capital problems when interest rates were stable, but did so during the early 1980s. This led the thrifts to quickly realize the need to sell off their mortgage loans into the secondary market. Thus followed the development of U.S. mortgage banks, who originate and warehouse loans prior to reselling them; such banks held 35 percent of residential mortgage originations in 1990 and around 55 percent by 1996 (Coles and Hardt, 2000). The secondary market buyers are primarily U.S. GSEs. Accordingly, interest rate and prepayment risks are sold to third parties. The U.S. is the world's largest and most developed residential MBS market.

Though the Canadian banks were exposed to similar economic circumstances as the thrifts in the U.S., they did not face severe capital crunches due to the substantially shorter mortgage loan terms that enabled a greater match with term deposits, debentures and investment certificates (Lea and Bernstein, 1995). Further, large nationwide banks and trust companies dominate the Canadian finance industry so that balancing capital requirements were easier than for the regional thrifts in the U.S., as the Canadian institutions serve all regions of the country. For these reasons the institutions were able to originate loan portfolios for themselves rather than having to sell them on a secondary market. The Canadian finance industry significantly consolidated during the 1990s. The chartered banks' share of Canadian residential mortgages outstanding rose from 41.1 percent in 1990 to 61.4 percent in 2000, in line with the increasing prominence of the banks in the Canadian finance industry.

The government agencies play a dominant role in the U.S. as they purchase mortgage loan packages and either hold them on their balance sheet or securitize them by selling them into the secondary mortgage market. Three agencies are active participants in securitizations in the U.S. secondary market: the Government National Mortgage Association (GNMA or Ginnie Mae); the Federal Home Loan Mortgage Corporation (FHLMC or Freddie Mac); and the Federal National Mortgage Association (FNMA or Fannie Mae). Ginnie Mae securitizes government loans insured by the Federal Housing Administration (FHA).

Government loans are backed by the full faith and credit of the U.S. government, who guarantees the timely receipt of principal and interest. As Ginnie Mae paper has a zero percent risk weighting, the purchasers of Ginnie Mae securities do not need to allocate capital for risk.

Fannie Mae and Freddie Mac securitize conventional, conforming loans that are not explicitly guaranteed by the federal government. The U.S. secondary market has led to standardization of loan requirements on lenders, which leads to a degree of homogeneity in the market. Coles and Hardt (2000) report that this approach to mortgage funding results in a 
reduction in funding costs of about 50 basis points; that is, 0.5 percentage points, and that over 50 percent of residential mortgages were securitized at the end of 1997, which amounted to approximately $\$ 2$ trillion. As shown in Table 30, MBS are an important investment vehicle in the U.S.

Table 30

MBS: A Major Investment Vehicle

(Source: Federal Reserve Board, U.S. Treasury)

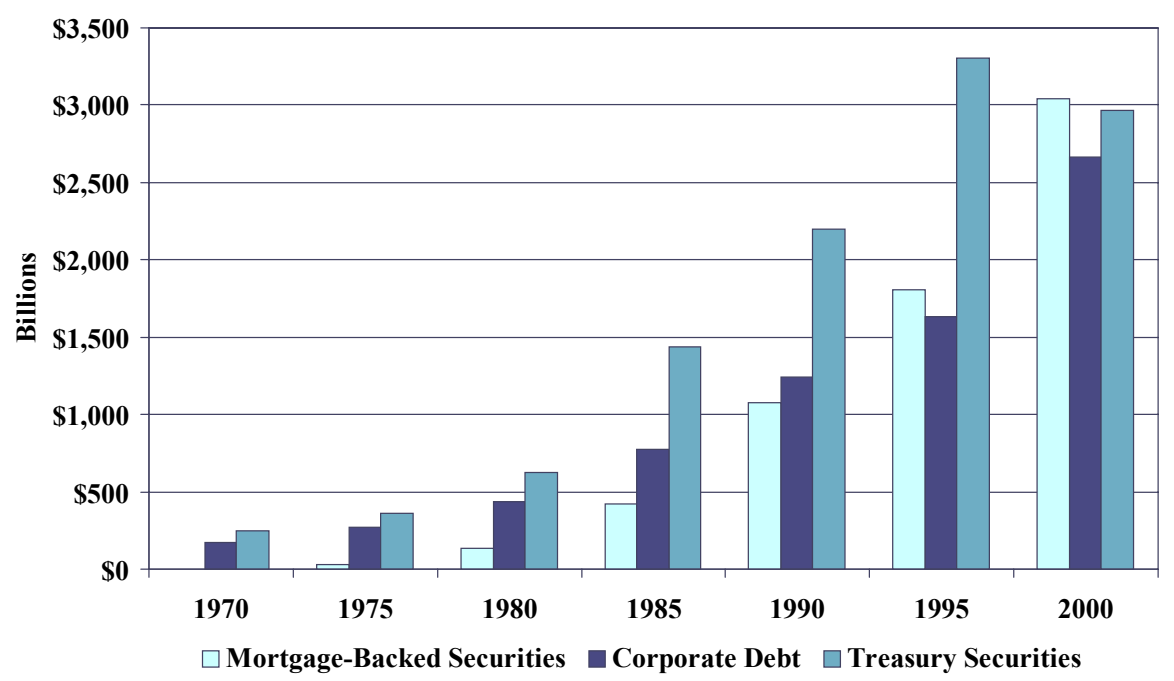

Over the last fifteen years the Canadian government has sought to diversify mortgage-funding sources, widen the terms and packages offered to borrowers and to lower mortgage-funding costs. CMHC, under the authorization of the government, began issuing mortgage-backed securities, consisting of NHA insured loans, in 1987. These securities, known now as Cannie Maes, were modeled on the U.S. Ginnie Maes. Growth exceeded most expectations during the first several years of the program (Jones, 1998 and Witherspoon, 1999). The mid 1990s saw a slow down due to some changes in NHA legislation and weak housing demand, but the growth rate is expected to increase as a flat yield curve will promote consumer preference for longer-term mortgages and a decline in term deposits at financial institutions along with anticipated growth in mortgage lending up to at least 2016 implies a need for external funding. Securitizing assets may also assist domestic Canadian banks to compete globally and domestically against foreign banks (Ard, 1998). Further, Canadian banks are looking to securitize mortgages in order to achieve greater return on equity (Tibbitts et al., 2000).

Nevertheless, the proportion of mortgages funded by the secondary market in Canada is still well below that in the U.S.; 7.4 percent of the residential mortgages outstanding (approximately \$32 billion) were funded from the secondary market at the end of 2000, which is 18 percent higher than the previous year.

While 5-year term issues dominate the NHA MBS issues, those with terms longer than 5 years account for approximately one-third of new issues; Table 31 provides a breakdown of the terms for those MBS issued in the first quarter of 2000 (CMHC, 2000b). 
Table 31

NHA MBS Issues by Term: 2000Q1

(Source: CHMC)

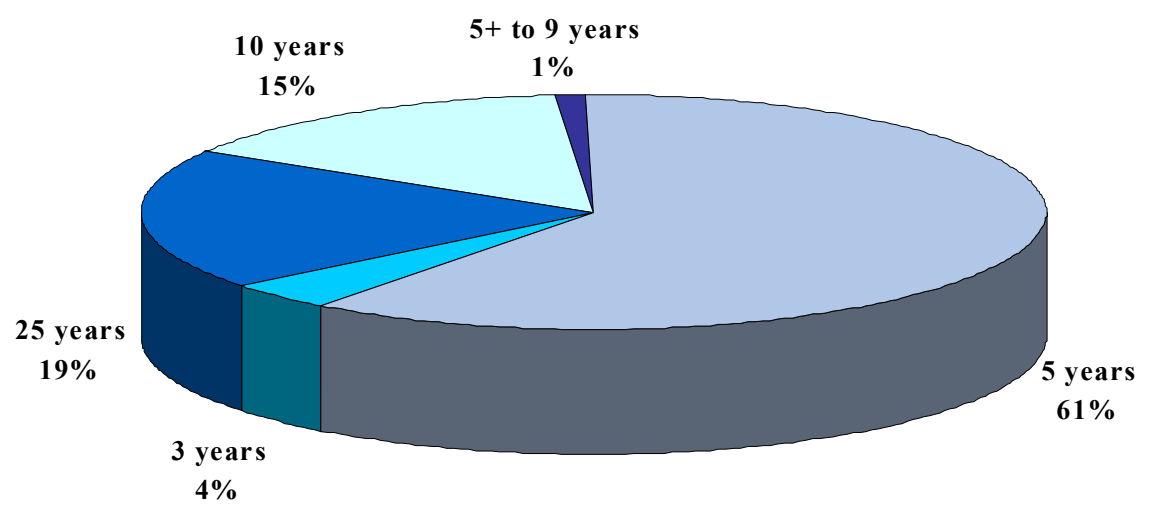

Chartered banks account for approximately 84 percent of new NHA MBS issues, trusts approximately 10 percent, with the remainder from loan and insurance companies. Initially, as most issues were relatively small (many less than $\$ 10$ million and only a few up to $\$ 100$ million), the issuance costs were high. This resulted in a large spread between the contract rates on loans included in MBS pools and the MBS coupon rate (approximately 100 to 200 basis points). Attempts have now been made to repackage several bundles into a single issue as well as to attract foreign investors by exempting such from Canadian withholding tax requirements.

The various pools of NHA MBS vary according to whether they are comprised of exclusively homeowner mortgages, multi-family rental mortgages, social housing mortgages (such as co-ops and senior residences) and a mixture of any of these types and on the pass through of prepayment penalties to the investor. The social housing pools are less risky than the other pools, as social housing loans are not prepayable. The mix of the others between partial and full prepayments is of significant interest in Canada given the severe prepayment penalties, as unlike full prepayments, partial prepayments impact on the remaining amortization period for a mortgage pool and so on the derivatives based on the interest portion (Jones, 1998).

The latest CMHC finance initiative in the secondary market, made possible by 1999 amendments to the NHA and the CMHC Act, is the introduction of Canada Mortgage Bonds (CMB) that aim to provide an alternative and competitive source of funds for the mortgage market that may assist in reducing the cost of mortgage financing. CMB will be issued through a newly created special purpose trust - the Canada Housing Trust (CHT) - and will be semi-annual coupon, fixed rate, bullet maturity bonds that carry the full guarantee of the Government of Canada via CMHC. Investors will be provided with a bond like investment, as CHT will convert the monthly cash flows from NHA MBS pools into non-amortizing bond cash flows with fixed interest payments and principal at maturity. CMB will be issued in 
denominations as low as $\$ 1,000$ and can be issued for any term, though the inaugural issue in June 2001 is for five years. This issue is anticipated to exceed $\$ 1.5$ billion and is expected to trade at a modest yield premium to Government of Canada bond issues. CHT will use the proceeds to purchase mortgages packaged in newly issued NHA MBS pools that meet a certain eligibility criteria; e.g., each pool must have a minimum portfolio value of $\$ 20$ million and contain mortgages that mature no sooner than six months prior to bond maturity.

\section{Concluding Remarks}

In summary, despite similar homeownership rates, the structure of the mortgage markets, the public policy objectives, the rates, terms and products of mortgage instruments all substantially differ across the two countries. These disparities do not appear to result from differences in the demographics affecting housing demand across the two countries. They do not appear to result from any significant variations in the volatility in housing markets and in the share of housing relative to GDP.

We conclude that many of the differences come from the public policy objectives across the two countries. The leadership of the CHMC in setting terms on government loans led to the adoption of shorter term mortgages for the NHA products, a practice quickly adopted by the chartered banks, and which shifted interest rate risk to borrowers. The longer term loan practices in the U.S. led to interest rate risk being shifted to the global market with the development of mortgage securitization; there was no such need in Canada as borrowers did not have the power to influence the government to follow the U.S. route. Further, Canada has often used homeowner incentive schemes, rather than affecting outcomes through policies on the supply side. An additional factor leading to substantially different products across the two countries is likely the relatively concentrated primary mortgage finance market in Canada. There are no particular incentives for banks to move now toward any products as favorable to borrowers as those most typically preferred in the U.S. 


\section{References}

Anderson, G., 1992, Housing Policy in Canada: Lecture Series, CMHC.

Archer, W.R., Ling, D.C. and McGill, G.A., 1996, The effect of income and collateral constraints on residential mortgage terminations, Regional Science and Urban Economics $26,235-261$.

Ard, E.A., 1998, A new frontier: banks to lead securitization charge in Canada, Structured Finance, June, 15-18.

Baer, W.C., 1975, On the making of perfect and beautiful social programs, Public Interest 39, $80-98$.

Bennett, P., Peach, R. and Peristiani, S., 2000, Implied mortgage refinancing thresholds, Real Estate Economics 28, 405-434.

Bourassa, S.C. and Grigsby, W.G., 2000, Income tax concessions for owner-occupied housing, Housing Policy Debate 11, 521-573.

Breslow, J., Irvine, I. and Rahman, A., 1996, Instrument choice: the demand for mortgages in Canada, Journal of Urban Economics 39, 282-302.

Capozza, S.G., Green, R.K., and Hendershott, P.H., 1997, Taxes and house prices, Working Paper Series No.97-16. Ohio State University, Charles A. Dice Center for Research in Financial Economics.

Carter, T., 1997, Current practices for procuring affordable housing: the Canadian context, Housing Policy Debate 8, 593-631.

Canadian Home Income Plan (CHIP), 2001, Who is CHIP?, www.chip.ca.

Coles A. and Hardt, J., 2000, Mortgage markets: why US and EU markets are so different, Housing Studies 15, 775-783.

Courchane and Nickerson (2001). Comparing international mortgage markets: key information," working paper, Freddie Mac.

CMHC, 1985, Consultation Paper on Housing, CMHC: Ottawa.

CMHC, 1986, Annual Report, CMHC: Ottawa.

CMHC, 1988, The Housing Industry: Perspective and Prospective Summary Report - The Changing Housing Industry in Canada, 1946-2001, CMHC: Ottawa.

CMHC, 2000a, Housing Facts, April, CMHC: Ottawa. 
CMHC, 2000b, Mortgage Market Trends, $2^{\text {nd }}$ quarter, CMHC: Ottawa.

CMHC, 2001, Home to Canadians Annual Report 2000, April, CMHC: Ottawa.

Deng, Y., Quigley, J.M. and Van Order, R., 2000, Mortgage terminations, heterogeneity and the exercise of mortgage options, Econometrica 68, 275-307.

Dowler, R.G., 1983, Housing Related Tax Expenditures: An Overview and Evalutaion, Report No.22, Centre for Urban and Community Studies, University of Toronto: Toronto.

Dreier, P., 1997, The new politics of housing: how to rebuild the constituency for a progressive federal housing policy, Journal of the American Planning Association 63, 5-27.

Engelhardt, G.V., 1996, Tax subsidies and household saving: evidence from Canada, Quarterly Journal of Economics 111, 1237-1268.

Engelhardt, G.V., 1997, Do targeted savings incentives for home ownership work? The Canadian experience, Journal of Housing Research 8, 225-248.

Engelhardt, G.V. and Poterba, J.M., 1991, House prices and demographic change, Journal of Regional Science and Urban Economics 21, 539-546.

Follain, J.R. and Dunsky, R.M., 1997, The demand for mortgage debt and the income tax, Journal of Housing Research 8, 155-199.

Foot, D.K. and Stoffman, D., 1999, Boom, Bust and Echo 2000: Profiting from the Demographic Shift in the New Millennium, Boréal: Montreal.

Fortin, M. and Leclerc, A., 1999, Demographic changes and real housing prices in Canada, CMHC Housing Affordability and Finance Series, CMHC.

Gates, S. W. and D. Kirk, 2001, "Prepayment penalties on residential subprime mortgages: market defense or predatory offense?" working paper.

Goode, R., 1960, Imputed rent of owner-occupied dwellings under the income tax, Journal of Finance, 15, 504-530.

Green, R.K. and LaCour-Little, M., 1999, Some truths about ostriches: who doesn't prepay their mortgages and why they don't, Journal of Housing Economics 8, 233-248.

Green, R.K. and Shoven, J.B., 1986, The effects of interest rates on mortgage prepayments, Journal of Money, Credit and Banking 18, 41-59.

Green, R.K. and Vandell, K.D., 1999, Giving households credit: how changes in the U.S. tax code could promote homeownership, Regional Science and Urban Economics 29, 419444. 
Harris, R. and Ragonetti, D., 1998, Where credit is due: residential mortgage finance in Canada, 1901 to 1954, Journal of real Estate Finance and Economics, 16, 223-238.

Hendershott, P.H., 1991, Are real house prices likely to decline by 47 percent? Journal of Regional Science and Urban Economics 21, 553-563.

Hendershott, P.H. and Hu, S.-C., 1981, Inflation and extraordinary returns on owner-occupied housing: some implications for capital allocation and productivity growth, Journal of Macroeconomics 3, 177-203.

Hulchanski, J.D., 1990, Canada, in International Handbook of Housing Policies and Practices, ed., E. van Vliet, Greenwood Press: New York, 289-325.

Jones, L.D., 1993, Deficiency judgments and the exercise of the default option in home mortgage loans, Journal of Law and Economics, 36, 115-138.

Jones, L.D., 1994, Home mortgage debt financing of nonhousing investments, Journal of Real Estate Finance and Economics 9, 91-112.

Jones, L.D., 1995, Net wealth, marginal tax rates and the demand for home mortgage debt, Regional Science and Urban Economics 25, 297-322.

Jones, L.D., 1998, The evolving Canadian housing finance system and the role of government, in Secondary Mortgage Markets: International Perspective, ed., M.J. Lea, International Union for Housing Finance: Chicago, 89-97.

LaCour-Little, M., 1999, Another look at the role of borrower characteristics in predicting mortgage prepayments, Journal of Housing Research 10, 45-60.

Lea, M.J., 2000, Prerequisites for a successful secondary mortgage market: the role of the primary mortgage market, Housing Finance International, 15, 2.

Lea, M.J. and Bernstein, S.A., 1995, International Housing Finance Sourcebook, $3^{\text {rd }}$ Edition, International Union for Housing Finance: Chicago.

Lea, M.J. and Renaud, B., 1994, Contract savings for housing: relevancy for U.S. housing finance, Fannie Mae: Washington, D.C.

Mankiw, N.G. and Weil, D.N., 1989, The baby boom, the baby bust and the housing market, Journal of Regional Science and Urban Economics 19, 235-258.

Pape, G., 2001, Gordon Pape Report May 222001 to May 28 2001, CBC Transcripts. Available from www.gordonpape.com.

Peristiani, S., Bennett, P., Monsen, G., Peach, R. and Raiff, J., 1997, Credit, equity and mortgage refinancings, Federal Reserve Bank of New York Economic Policy Review, 3, 83-99. 
Pierce, B.J., 1989, Homeowner preferences: the equity and revenue effects of proposed changes in the status quo, Journal of the American Taxation Association 10, 54-67.

Pitkin, J.R. and Myers, W., 1994, The specification of demographic effects on housing demand: avoiding the age-cohert fallacy, Journal of Housing Economics 3, 240-250.

Poapst, J.V., 1975, Canada's federal mortgage exchange corporation, American Real Estate and Urban Economics Association Journal, 3, 7-21.

Quigley, J.M., 1987, Interest rate variations, mortgage prepayments, and household mobility, Review of Economics and Statistics, 69, 636-643.

Tibbitts, L., French, D., and Landry, B., 2000, Standard and Poor's Rating Services.

Turner, G., 2001, How to borrow and win: Turner report, Oak Bay Weekend Edition, May 25, 20.

Unger, M.L., 1977, The Canadian mortgage market and the renegotiable term mortgage, in Alternative Mortgage Instruments Research Study, Vol. II, Federal Home Bank Board: Washington, D.C.

Van Dyk, N., 1995, Financing social housing in Canada, Housing Policy Debate 6, 815-848.

Vandell, K.D., 2000, Comment on Steven C. Bourassa and William G. Grigsby's "Income tax concessions for owner-occupied housing", Housing Policy Debate 11, 561-573.

Voith, R., 1999, Does the federal tax treatment of housing affect the pattern of metropolitan development? Federal Reserve Bank of Philadelphia Business Review, March-April, 316.

Weicher, J.C., 2000, Comment on Steven C. Bourassa and William G. Grigsby's "Income tax concessions for owner-occupied housing”, Housing Policy Debate 11, 547-559.

White, M.J. and White, L.J., 1977, The tax subsidy to owner-occupied housing: who benefits?, Journal of Public Economics 3, 111-126.

Witherspoon, I., 1999, The National Housing Act Mortgage-Backed Securities Program in Canada, Housing Finance International, June 17-22.

Woodward, S.E. and Weicher, J.C., 1989, Goring the wrong ox: a defense of mortgage interest deduction, National Tax Journal 42, 301-313.

Yang, T.T., Buist, H. and Megbolugbe, I.F., 1998, An analysis of the ex ante probabilities of mortgae prepayment and default, Real Estate Economics 26, 651-676.

Zorn, P.M. and Lea, M.J., 1989, Mortgage borrower repayment behavior: a microeconomic analysis with Canadian adjustable rate mortgage data, American Real Estate and Urban Economics Association Journal, 17, 118-36. 
Table 26

Illustrative Spreads Between Closed and Open Mortgages Interest Rates in Canada

\begin{tabular}{|c|c|c|c|c|c|c|c|c|c|c|c|c|}
\hline \multirow[t]{2}{*}{ Institution } & \multicolumn{6}{|c|}{ as at August 2, 2000} & \multicolumn{6}{|c|}{ as at June 1,2001} \\
\hline & $\begin{array}{l}6 \text {-mth } \\
\text { closed \% }\end{array}$ & $\begin{array}{l}\text { 6-mth } \\
\text { open \% }\end{array}$ & $\begin{array}{l}\text { Spread } \\
\% \text { points }\end{array}$ & $\begin{array}{l}1 \text {-year } \\
\text { closed }\end{array}$ & $\begin{array}{l}\text { 1-year } \\
\text { open }\end{array}$ & $\begin{array}{l}\text { Spread } \\
\text { \% points }\end{array}$ & $\begin{array}{l}\text { 6-mth } \\
\text { closed }\end{array}$ & $\begin{array}{l}\text { 6-mth } \\
\text { open }\end{array}$ & $\begin{array}{l}\text { Spread } \\
\% \text { points }\end{array}$ & $\begin{array}{l}1 \text {-year } \\
\text { closed }\end{array}$ & $\begin{array}{l}\text { 1-year } \\
\text { open }\end{array}$ & $\begin{array}{l}\text { Spread } \\
\text { \% points }\end{array}$ \\
\hline $\begin{array}{l}\text { Bank of } \\
\text { Montreal }\end{array}$ & 8.15 & 8.60 & 0.45 & 7.90 & 8.70 & 0.80 & 7.00 & 7.45 & 0.45 & 6.70 & 7.45 & 0.75 \\
\hline $\begin{array}{l}\text { Canada } \\
\text { Trust }\end{array}$ & 8.15 & 8.60 & 0.45 & 7.90 & n.a. & n.a. & 7.00 & 7.45 & 0.45 & 6.70 & n.a. & n.a. \\
\hline CIBC & 8.15 & 8.60 & 0.45 & 7.90 & 8.70 & 0.80 & 7.00 & 7.45 & 0.45 & 6.70 & 7.50 & 0.80 \\
\hline $\begin{array}{l}\text { Citizens } \\
\text { Bank }\end{array}$ & 7.65 & 8.10 & 0.45 & 7.40 & 8.20 & 0.80 & 6.50 & 6.95 & 0.45 & 6.20 & 7.00 & 0.80 \\
\hline $\begin{array}{l}\text { First } \\
\text { Calgary } \\
\text { Savings }\end{array}$ & 8.20 & 8.65 & 0.45 & 7.95 & 8.75 & 0.80 & 7.00 & 7.45 & 0.45 & 6.70 & 7.45 & 0.75 \\
\hline $\begin{array}{l}\text { HSBC } \\
\text { Bank } \\
\text { Canada }\end{array}$ & 8.15 & 8.60 & 0.45 & 7.90 & 8.70 & 0.80 & 7.00 & 7.45 & 0.45 & 6.70 & 7.50 & 0.80 \\
\hline $\begin{array}{l}\text { Investors } \\
\text { Group } \\
\text { Trust } \\
\end{array}$ & 8.15 & 8.60 & 0.45 & 7.90 & 8.70 & 0.80 & 7.00 & 7.45 & 0.45 & 6.70 & 7.50 & 0.80 \\
\hline $\begin{array}{l}\text { London } \\
\text { Life }\end{array}$ & 8.15 & 8.60 & 0.45 & 7.90 & 8.70 & 0.80 & 7.00 & 7.45 & 0.45 & 6.70 & 7.50 & 0.80 \\
\hline $\begin{array}{l}\text { MRS } \\
\text { Trust }\end{array}$ & 7.39 & 8.09 & 0.70 & 7.39 & n.a. & n.a. & 6.25 & 6.80 & 0.55 & 6.25 & n.a. & n.a. \\
\hline $\begin{array}{l}\text { Royal } \\
\text { Bank } \\
\end{array}$ & 8.20 & 8.65 & 0.45 & 7.95 & 8.75 & 0.80 & 7.00 & 7.45 & 0.45 & 6.70 & 7.50 & 0.80 \\
\hline $\begin{array}{l}\text { Toronto } \\
\text { Dominion }\end{array}$ & 8.15 & n.a. & n.a. & 7.90 & 8.70 & 0.80 & 7.00 & n.a. & n.a. & 6.70 & 7.45 & 0.75 \\
\hline
\end{tabular}



Table 27

Canada: Comparison of Closed Variable \& Fixed-Term Mortgage Rates as at June 1, 2001

\begin{tabular}{|l|l|l|l|l|l|l|l|}
\hline Financial & \multicolumn{9}{|c|}{ Term } \\
\cline { 2 - 8 } Institution & Variable & 6 & $\begin{array}{l}1- \\
\text { months } \\
\text { year }\end{array}$ & $\begin{array}{l}2- \\
\text { years }\end{array}$ & $\begin{array}{l}3- \\
\text { years }\end{array}$ & $\begin{array}{l}4- \\
\text { years }\end{array}$ & $\begin{array}{l}5- \\
\text { years }\end{array}$ \\
\hline $\begin{array}{l}\text { Bank of } \\
\text { Montreal }\end{array}$ & 4.00 & 7.00 & 6.70 & 7.05 & 7.30 & 7.65 & 7.75 \\
\hline $\begin{array}{l}\text { CIBC } \\
\text { Mortgages }\end{array}$ & 5.24 & 7.00 & 6.70 & 7.05 & 7.30 & 7.65 & 7.75 \\
\hline $\begin{array}{l}\text { Fede Des } \\
\text { Caisses De } \\
\text { Mti }\end{array}$ & 6.15 & 7.00 & 6.70 & 7.05 & 7.30 & 7.65 & 7.75 \\
\hline $\begin{array}{l}\text { FirstLine } \\
\text { Mortgages }\end{array}$ & 5.99 & 7.00 & 6.80 & 6.85 & 6.95 & n.a. & 7.04 \\
\hline $\begin{array}{l}\text { MCAP } \\
\text { Mortgage }\end{array}$ & 5.85 & 7.00 & 6.70 & 7.05 & 7.30 & 7.65 & 7.75 \\
\hline $\begin{array}{l}\text { Master } \\
\text { Choice }\end{array}$ & 4.99 & 6.00 & 5.70 & n.a. & 6.49 & n.a. & 6.71 \\
\hline $\begin{array}{l}\text { President's } \\
\text { Choice }\end{array}$ & 4.74 & 5.99 & 6.84 & 6.95 & 6.94 & 6.99 & 6.99 \\
\hline
\end{tabular}

Source: CANNEX Financial Exchanges Limited (http: \\www.cannex.com/canada) 
Table 28

Canada: Comparison of Some Mortgage Product Features Between the 1970s and 1990s

\begin{tabular}{|c|c|c|}
\hline Product Feature & 1990s & 1970s \\
\hline Term Options & $\begin{array}{l}\text { Closed, open and } \\
\text { convertible mortgages } \\
\text { are available. } \\
\text { Convertible offers } \\
\text { lower rates than same } \\
\text { term open mortgages } \\
\text { and also allows } \\
\text { individuals to change } \\
\text { to a closed term or } \\
\text { another convertible } \\
\text { term without penalty. }\end{array}$ & $\begin{array}{l}\text { Only 5-year or lower } \\
\text { closed mortgages } \\
\text { were available. }\end{array}$ \\
\hline Pricing Plans & $\begin{array}{l}\text { - Fixed rate, variable } \\
\text { rate, multi-rate, rate } \\
\text { capped. }\end{array}$ & $\begin{array}{l}\text { Only 5-year or lower } \\
\text { closed mortgages } \\
\text { were available. }\end{array}$ \\
\hline Terms Available & $\begin{array}{l}6 \text { month, 1-year, 2- } \\
\text { year, 3-year, 4-year, } \\
\text { 5-year, 7-year, 10- } \\
\text { year, 15-year, 20- } \\
\text { year; split and } \\
\text { staggered terms. }\end{array}$ & $\begin{array}{l}\text { Only 5-year or lower } \\
\text { closed mortgages } \\
\text { were available. }\end{array}$ \\
\hline Payment Plans & $\begin{array}{l}\text { Monthly, semi- } \\
\text { monthly, bi weekly, } \\
\text { weekly and } \\
\text { accelerated. }\end{array}$ & $\begin{array}{l}\text { - Only monthly } \\
\text { payment plans were } \\
\text { available. }\end{array}$ \\
\hline Interest Rates & $\begin{array}{l}\text { Discounts of one } \\
\text { quarter to a full } \\
\text { percent off of posted } \\
\text { rates. }\end{array}$ & $\begin{array}{l}\text { - All mortgages were at } \\
\text { posted rates. }\end{array}$ \\
\hline Prepayment Provisions & $\begin{array}{l}\text { Double up your } \\
\text { payment features; } \\
\text { monthly increases; } \\
\text { annual prepayment } \\
\text { allowances without } \\
\text { penalty. } \\
\text { Penalties of three- } \\
\text { month interest or } \\
\text { interest differential if } \\
\text { prepaid early, though } \\
\text { this may be waived or } \\
\text { lowered. }\end{array}$ & $\begin{array}{l}\text { Typically no } \\
\text { provisions for } \\
\text { prepayment or } \\
\text { accelerated payment. } \\
\text { If they did exist then } \\
\text { three month interest } \\
\text { penalty. }\end{array}$ \\
\hline Flexibility Options & $\begin{array}{ll}\text { - } & \text { Portability } \\
\text { - } & \text { Early renewal } \\
\text { - } & \text { Increases to loans } \\
\end{array}$ & $\begin{array}{l}\text { Early renewal and } \\
\text { extending the term } \\
\text { were not available. } \\
\text { Increases of mortgage } \\
\text { at existing rates rarely } \\
\text { available. }\end{array}$ \\
\hline
\end{tabular}

Source: Canada Mortgage.com (http: \www.canadamortgage.com) and Jones (1998). 
Table 29

Home Mortgage Disclosure Data: 1993 - 1999

Conventional Single Family

Subprime

Manufactured Housing

Prime Conforming

Prime Jumbo

HMDA Volumes: U.S.

Dollar Volume (In billions)

1999

1998

1996

19951994

1993

$91 \quad 40$

18

16

14

12

10

803

419

402

323

386

646

FHA, VA, RHS

Single Family

$217 \quad 255$

162

125

102

135

189

Total Single Family

$\begin{array}{rrrrrrr}134 & 150 & 101 & 95 & 75 & 87 & 151 \\ 1,097 & 1,315 & 735 & 653 & 522 & 628 & 996\end{array}$

HMDA Shares: U.S.

Percentage Shares for Single Family

$\begin{array}{lrrrrrr} & \mathbf{1 9 9 8} & \mathbf{1 9 9 7} & \mathbf{1 9 9 6} & \mathbf{1 9 9 5} & \mathbf{1 9 9 4} & \mathbf{1 9 9 3} \\ & 6.9 \% & 5.4 \% & 3.0 \% & 2.3 \% & 2.2 \% & 0.7 \% \\ \begin{array}{l}\text { Subprime } \\ \begin{array}{l}\text { Manufactured } \\ \text { Housing }\end{array}\end{array} & 1.2 \% & 1.9 \% & 1.8 \% & 1.8 \% & 1.2 \% & 0.3 \% \\ \begin{array}{l}\text { Prime } \\ \text { Conforming }\end{array} & 61.1 \% & 56.9 \% & 61.5 \% & 61.9 \% & 61.4 \% & 64.9 \% \\ & 19.4 \% & 22.1 \% & 19.2 \% & 19.6 \% & 21.4 \% & 19.0 \% \\ & & & & & & \\ \text { Prime Jumbo } & 11.4 \% & 13.8 \% & 14.6 \% & 14.4 \% & 13.8 \% & 15.2 \% \\ & 100.0 \% & 100.0 \% & 100.0 \% & 100.0 \% & 100.0 \% & 100.0 \%\end{array}$

Total Single Family

$\begin{array}{llllll}100.0 \% & 100.0 \% & 100.0 \% & 100.0 \% & 100.0 \% & 100.0 \%\end{array}$ 